\title{
Selected Aspects of Sustainable Mobility Reveals Implementable Approaches and Conceivable Actions
}

\author{
Suprava Chakraborty ${ }^{1}$, Nallapaneni Manoj Kumar ${ }^{2, *}{ }^{\circledR}$, Arunkumar Jayakumar ${ }^{3}{ }^{\circledR}$, Santanu Kumar Dash ${ }^{1} \mathbb{C}$ \\ and Devaraj Elangovan ${ }^{1}$ (D) \\ 1 TIFAC-CORE, Vellore Institute of Technology (VIT), Vellore 632014, Tamil Nadu, India; \\ suprava1008@gmail.com (S.C.); santanu4129@gmail.com (S.K.D.); elangovan.devaraj@vit.ac.in (D.E.) \\ 2 School of Energy and Environment, City University of Hong Kong, Kowloon, Hong Kong \\ 3 Department of Automobile Engineering, SRM Institute of Science and Technology, Kattankulathur 603203, \\ Tamil Nadu, India; arunkumj1@srmist.edu.in \\ * Correspondence: mnallapan2@cityu.edu.hk or nallapanenichow@gmail.com
}

Citation: Chakraborty, S.; Kumar, N.M.; Jayakumar, A.; Dash, S.K.; Elangovan, D. Selected Aspects of Sustainable Mobility Reveals Implementable Approaches and Conceivable Actions. Sustainability 2021, 13, 12918. http://doi.org/ $10.3390 /$ su132212918

Academic Editor: Armando Cartenì

Received: 22 September 2021

Accepted: 18 November 2021

Published: 22 November 2021

Publisher's Note: MDPI stays neutral with regard to jurisdictional claims in published maps and institutional affiliations.

Copyright: (C) 2021 by the authors. Licensee MDPI, Basel, Switzerland. This article is an open access article distributed under the terms and conditions of the Creative Commons Attribution (CC BY) license (https:/ / creativecommons.org/licenses/by/ $4.0 /)$.

\begin{abstract}
The transportation sector plays a prominent role in driving the economy of any given nation. However, with the recent tensions arising in and around the transportation sector, sustainable mobility concepts have evolved. However, it is quite unclear whether sustainable mobility is feasible and exhibits economic returns, environmental benefits, and societal advantages. Hence, taking into account the environmental, economic, and social impact, and technical possibilities, this study intends to analyse sustainable mobility in relation to economic returns, environmental benefits and societal advantages using bibliometric analysis. For this study, we considered two decades of research, from 2001 to 2021. An in-depth search was performed on articles generated in the last two decades to assess the state of the literature on sustainable mobility. The most reverent, frequently referenced papers and influential journals in the field of sustainable mobility were identified. The acquired findings highlight the most prominent publications, journals, and authors who have made significant contributions to sustainable mobility studies, as well as the sub-areas or themes linked to sustainable mobility. Overall, the analysis discovered current paradigms, significant research topics, and a relationship between the domains of sustainable mobility studies. Meanwhile, this study also demonstrates advancements in the primary themes and sub-areas during the previous 20 years and alterations in future research fields. In addition, this study identified the promotion of rapid-reliable-safe-convenient (RRSC) transportation services, reduction in urban car traffic, and support to low transportation demand as the critical steps that require immediate attention in order to build a sustainable mobility future. We also observed that hydrogen would be a promising fuel and potential technology for the future mobility sector in the post-COVID era.
\end{abstract}

Keywords: sustainable mobility; sustainable fuel vehicles; $\mathrm{CO}_{2}$ emission from vehicles; transportation and climate change; alternative fuel vehicles; car sharing; shared mobility; public transport

\section{Introduction}

Environmental degradation and global warming are being experienced worldwide due to the extensive use of fossil fuels. Several nations, as well as the European Union (EU), have agreed to lower their greenhouse gas (GHG) footprints under the Kyoto Protocol, which has set a target of decreasing GHGs by at least 18\% below 1990 levels by 2020 in its second commitment period [1]. Despite such commitments, January 2020 was the warmest January on record throughout the world [2]. This statistic represents the global warming trend that is directly connected to anthropogenic GHG emissions. Climate change caused by the emission of GHGs is the most significant environmental problem in contemporary society [3]. GHGs are not actually pollutants, because $\mathrm{CO}_{2}$ is a natural component of the atmospheric air. However, the high concentration of $\mathrm{CO}_{2}$ emitted as a result of anthropogenic activity contributes to global warming and eventually leads to 
climate change. To stabilise the climate, it is increasingly necessary to significantly reduce the emissions by understanding their origins and exploring the mitigation steps [4]. $\mathrm{CO}_{2}$ is the greatest GHG contributor, accounting for $76 \%$ of total GHG emissions. Methane, Nitrous Oxide and Fluorinated gases together contribute the remaining 24\% [5]. The worldwide concentration of $\mathrm{CO}_{2}$ is increasing exponentially, as shown in Figure 1.

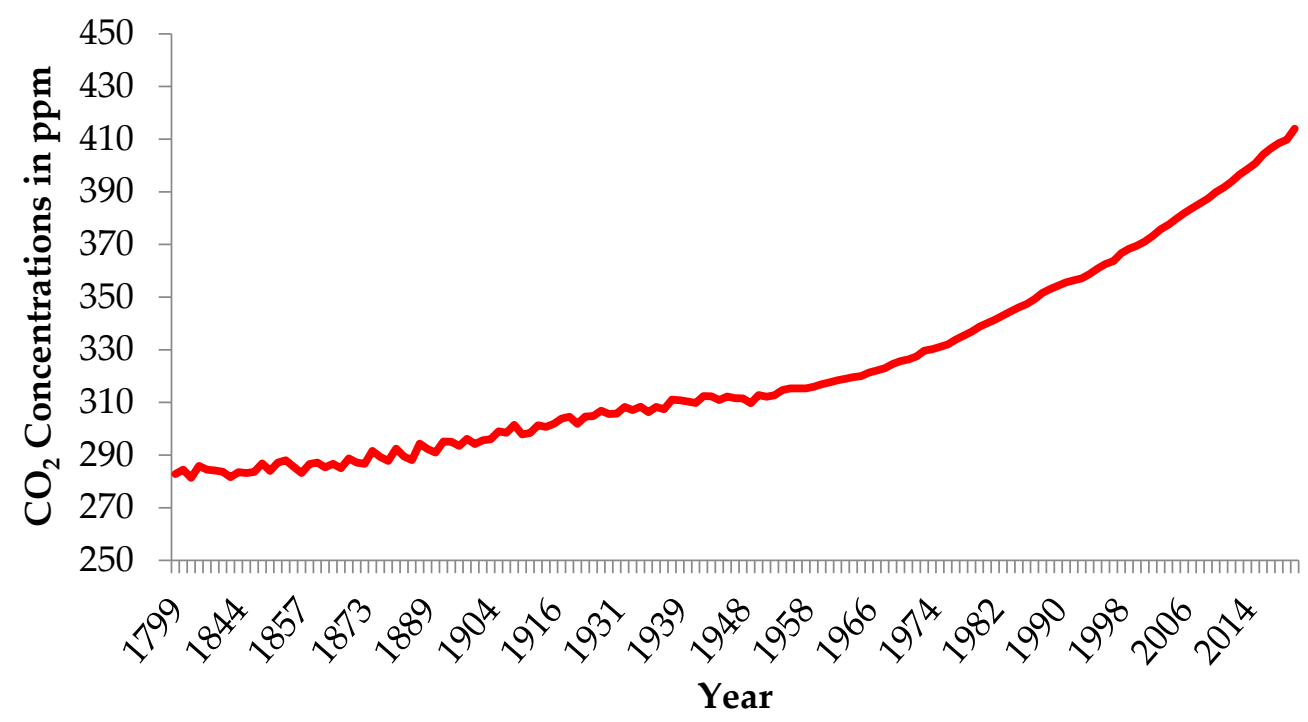

Figure 1. The concentration of $\mathrm{CO}_{2}$ in the atmosphere in ppm. Data collected from Refs. [6,7].

Detailed investigation of Figure 1 shows that the stiffness of the graph started increasing drastically since 1900. A more detailed investigation shows that in the last 20 years, the concentration of $\mathrm{CO}_{2}$ in the atmosphere increased by $44 \mathrm{ppm}$. See Figure 2.

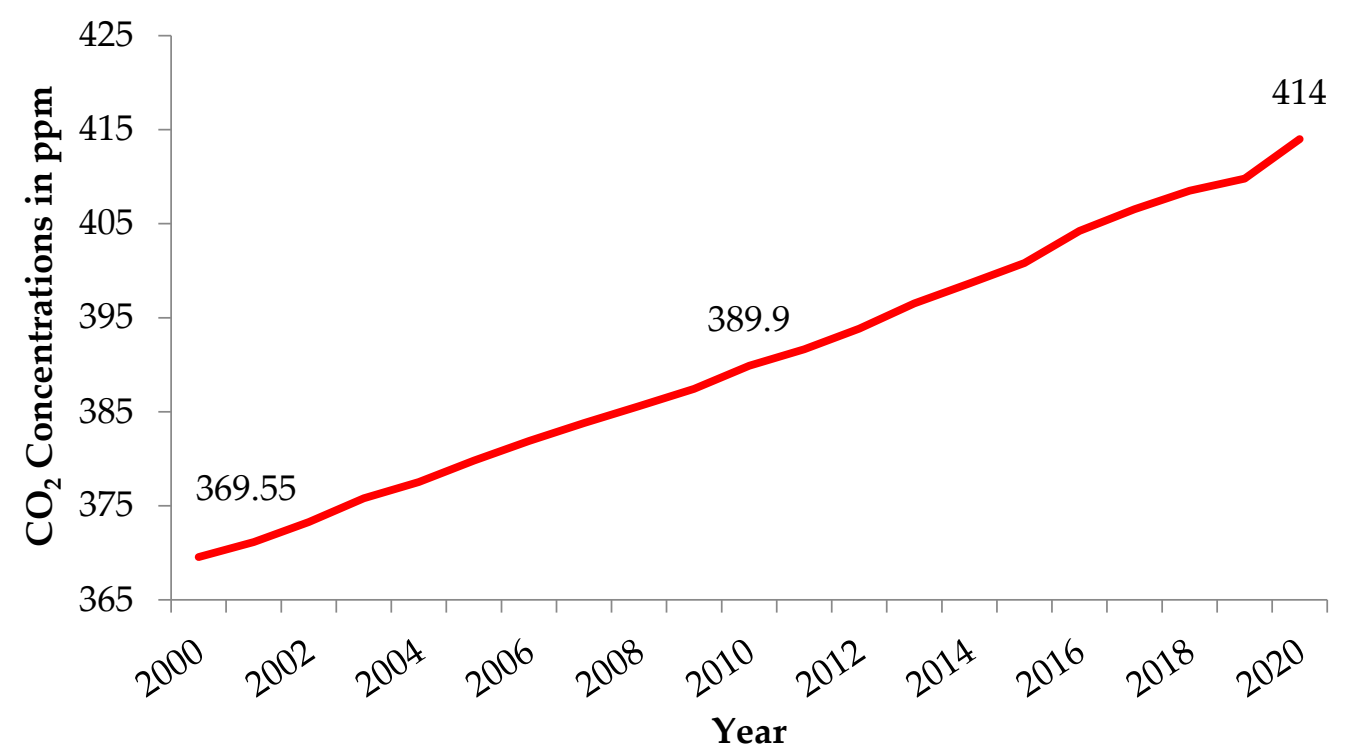

Figure 2. The concentration of $\mathrm{CO}_{2}$ in the atmosphere in ppm for the period of 2000-2020. Data collected from Refs. [6,7].

Earlier, the same increment took 30 years, i.e., 1970 to 2000, as depicted in Figure 3. Prior to that, an increase in the same concentration of $\mathrm{CO}_{2}$, i.e., $44 \mathrm{ppm}$, took 127 years (1843-1970), as presented in Figure 4. This continuous increase in the concentration of $\mathrm{CO}_{2}$ is caused by anthropogenic activities, indicating that the appropriate measures were neglected, especially during industrial revolutions. 


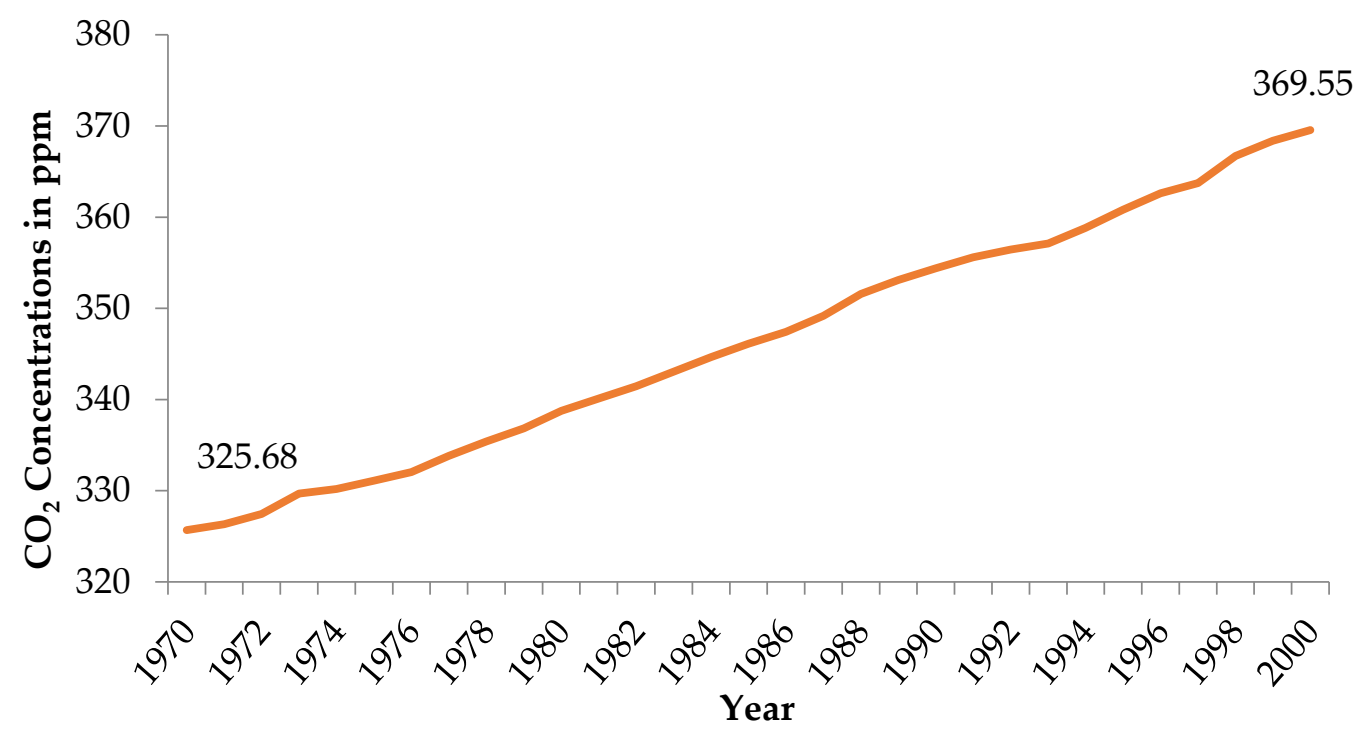

Figure 3. The concentration of $\mathrm{CO}_{2}$ in the atmosphere in ppm for the period of 1970-2000. Data collected from Refs. [6,7].

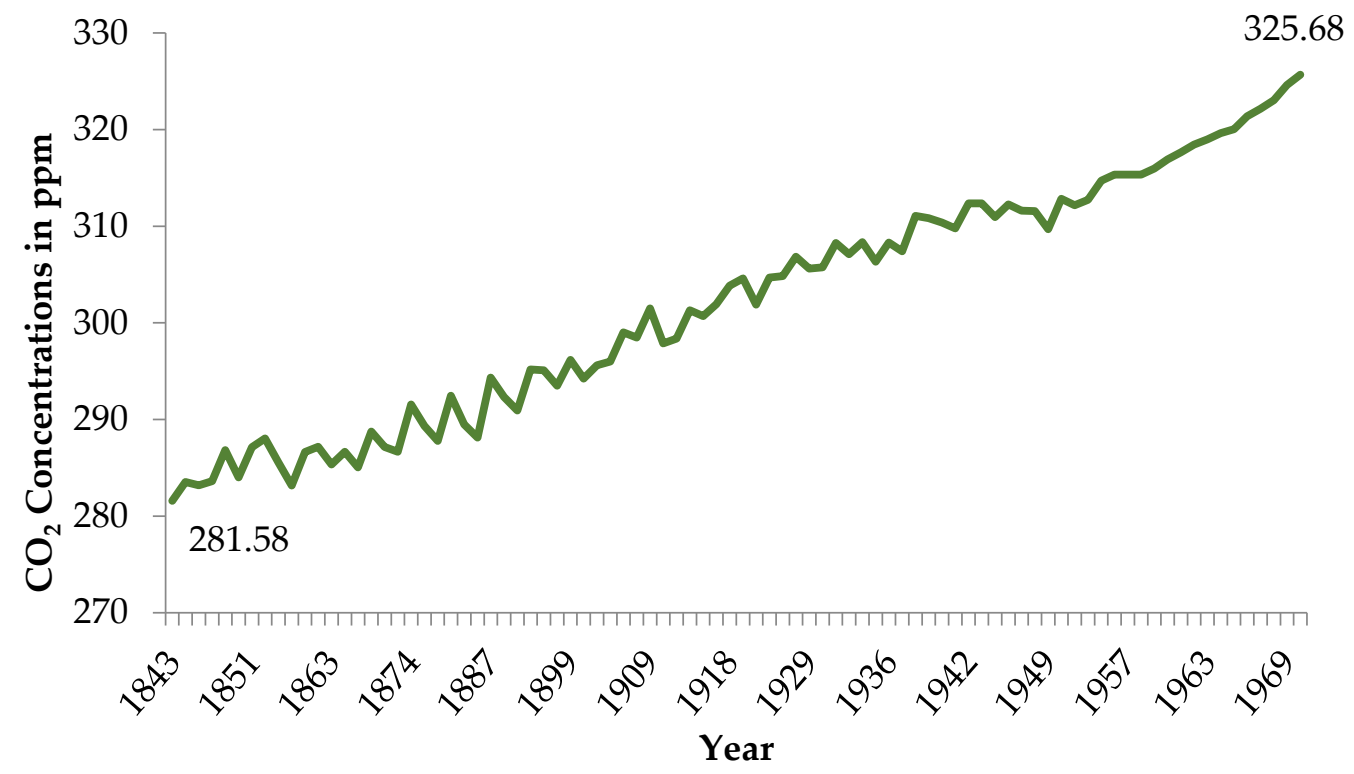

Figure 4. The concentration of $\mathrm{CO}_{2}$ in the atmosphere in ppm for the period of 1843-1970. Data collected from Refs. [6,7].

Currently, the concentration of atmospheric $\mathrm{CO}_{2}$ is more than $414 \mathrm{ppm}$, the highest ever in the last 800,000 years. This is correlated to the global temperature. The world has pledged to keep global warming well below $2{ }^{\circ} \mathrm{C}\left(3.6^{\circ} \mathrm{F}\right)$, and the target is achievable through a low carbon budget [6]. Researchers claim that the human community may only release $565 \mathrm{Gt}$ of $\mathrm{CO}_{2}$ more and try to reach the $2{ }^{\circ} \mathrm{C}$ target-a limit that would be depleted in 15 years if emissions continue at the current trend of $36.6 \mathrm{Gt}$ of $\mathrm{CO}_{2}$ each year [4]. It is estimated that around 7 million people die worldwide every year due to air pollution-borne diseases [8].

Transportation is considered the second biggest contributor towards pollution in terms of greenhouse gas emissions, resulting in a hazardous effect on human health. Sector-wise $\mathrm{CO}_{2}$ emissions in March 2021 are presented in Figure 5.

The transportation sector contributes $23 \%$ of total $\mathrm{CO}_{2}$ emissions. As per the assessment, the transportation sector is expected to remain dependent on petroleum-based products for $90 \%$ of its fleet, while only $10 \%$ will operate on renewable energy sources. It is 
also expected that carbon emissions from the transportation sector may remain $33 \%$ higher than 1990 levels by 2050 [9].

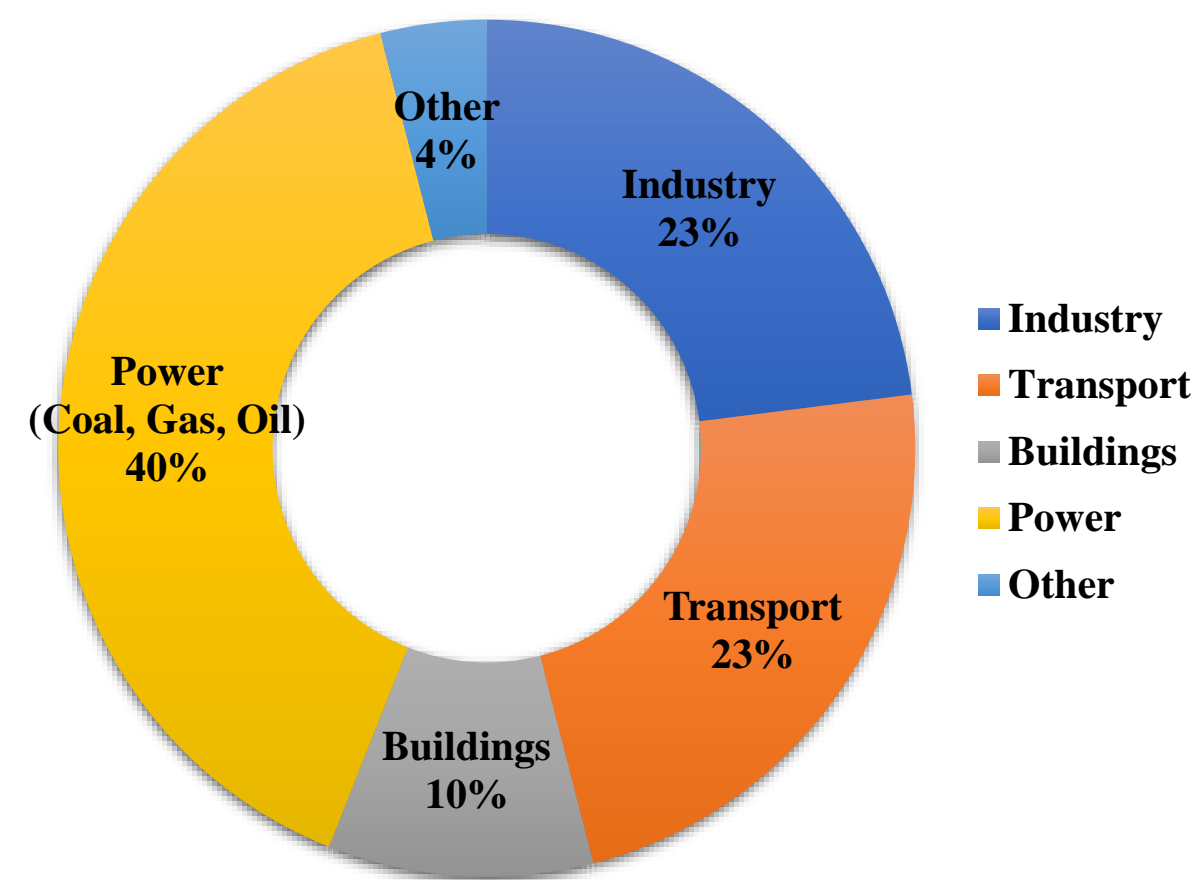

Figure 5. Sector-wise $\mathrm{CO}_{2}$ emission. Data collected from Ref. [10].

Due to forced confinement, there is a brief drop in daily worldwide $\mathrm{CO}_{2}$ emissions during COVID-19. Daily worldwide $\mathrm{CO}_{2}$ emissions have dropped by $17 \%$ at the beginning of April 2020 with respect to the mean levels of 2019, and half of this reduction is from surface transportation [11]. However, the scenario will be different in the post-COVID 19 situation; thus, adopting the sustainable mobility approach is essential. While GHGs can come from various sources, those released by automobiles can be decreased by using alternative fuel vehicles (AFVs) or green automobiles. Advanced alternative fuel technologies have the potential to drastically cut fuel consumption in half, while subsequently lowering $\mathrm{CO}_{2}$ emissions and their related environmental implications. While fuel-efficient technologies increase vehicle environmental performance, they cannot help reduce overall emissions. This is due to the reality that technology cannot modify consumption habits on its own. As a result, it is critical in developing a strategy that encourages consumers to choose energy-efficient vehicles over conventional ones and ensures that the use of AFVs complies with environmental pollution-reduction measures such as carpooling and using low $\mathrm{CO}_{2}$-emitting vehicles, public transportation, or bicycles to save fuel [12-14].

Hydrogen is an emerging and potential candidate as a fuel source for cars [15-17]. Hydrogen cars have been determined to have a threefold lower impact on global warming than other alternative technologies [18-20]. The COVID-19 crisis is a game-changer in transitioning from the carbon age to the new hydrogen age [21].

The originality of this study refers to presenting an up-to-date and critical literature analysis on the effects and prospects of sustainable mobility. The present review research focuses on the socio-economic-environmental aspects of sustainable mobility as well as its approaches and technical aspects, by reviewing 207 relevant sources from scholarly journals and media reports. This study aims to assess the possibilities and approaches of sustainable mobility and discuss its implications in socio-economic, environmental and technological terms. To that objective, a variety of hypotheses are suggested on the components that may impact customers' readiness to adopt the sustainable mobility option. The paper provides an insight to help the policy makers and industries prioritise sustainable mobility as the potential future. 
This paper is organized as follows; Section 2 deals with the methodology used to execute the critical review. Section 3 describes the broad view of sustainable mobility. Section 4 describes the environmental aspects of sustainable mobility. Section 5 discusses the socio-economic aspects of sustainable mobility. Section 6 describes the technical aspects of sustainable mobility in terms of sustainable fuel vehicles. Section 7 represents the different approaches to sustainable mobility. Section 8 concludes the complete analysis of the literature review.

\section{Methodology}

A comprehensive approach was followed to analyse and collect the most reputable and relevant publications for the study. This is due to the fact that a competent literature evaluation lays the groundwork for knowledge building. Consequently, thorough review research on content delivery was conducted. As seen in Figure 6, the procedure comprises five key searches on sustainable mobility, its environmental impact, social impact, economic impact, sustainable mobility approaches and technical aspects.

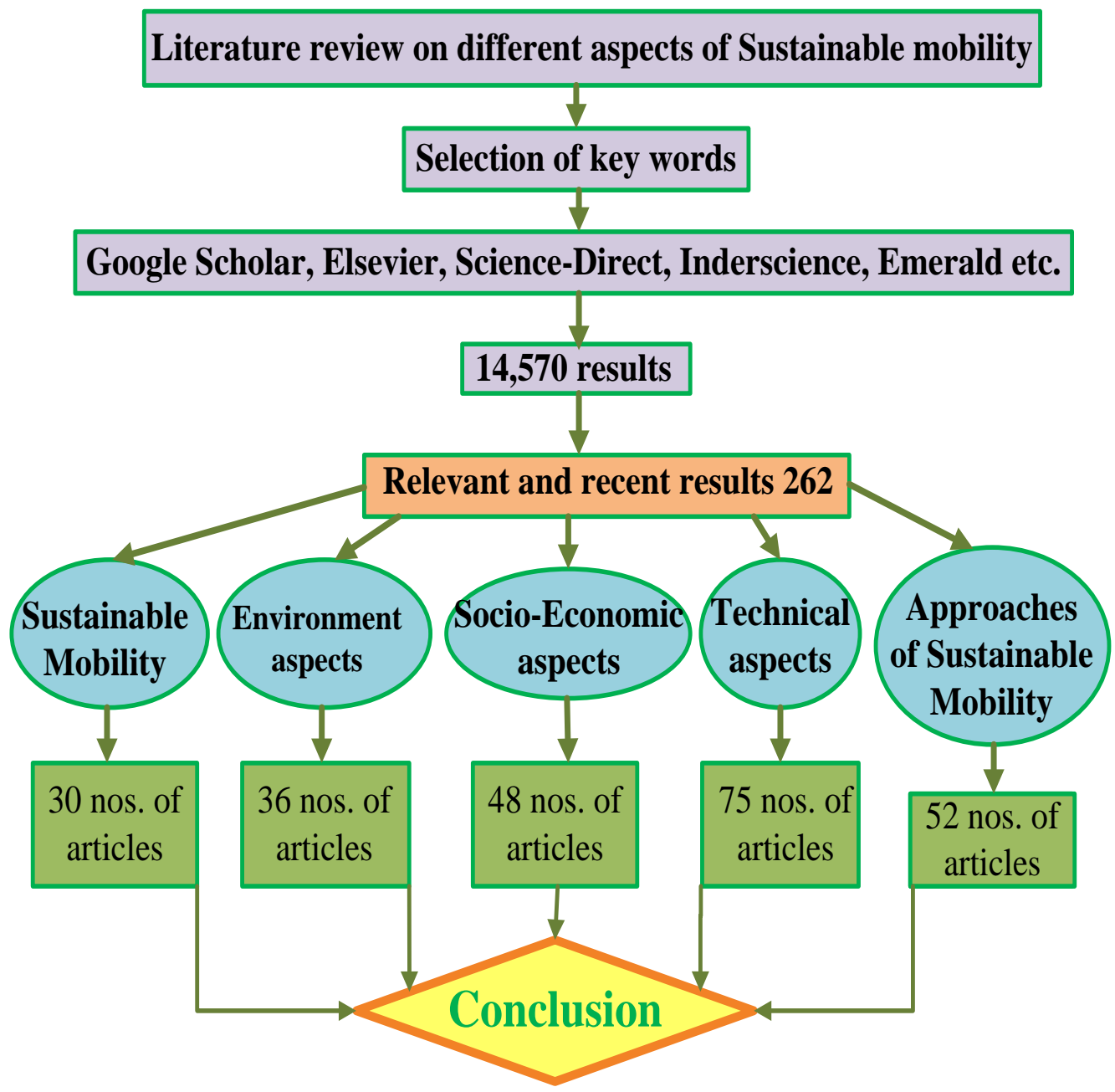

Figure 6. Flowchart for systematic research methodology.

The first step is a material acquisition, which entails getting research articles, abstracts, and unpublished material from Google Scholar, Elsevier, Science-Direct, IEEE, Springer, Taylor Francis, Wiley, Inderscience, and Emerald. Keywords such as 'sustainable mobility', 'environmental impact of sustainable mobility', 'societal impact of sustainable mobility', 'economic impact of sustainable mobility', 'sustainable mobility approaches' and 'technical aspects of sustainable mobility' were used to search the databases indicated above for 
appropriate materials. The search yielded a total of 14,570 results. Between 2001 and 2021, 14,464 resources were published, including 11,431 academic journals, 1694 conference materials, 502 magazines, 364 trade publications, and 183 books. The methodology of the paper is depicted in Figure 6.

A second step was created to find the most relevant information from popular publications. By the end of the second iteration round, the number of materials chosen had been whittled down to 329. Only articles and research papers that had been peer-reviewed were considered. Abstracts and unpublished theses were not considered. Of the 329 items, 262 were considered relevant. To reduce the number, the year of publication was utilised. The most recent publications were chosen for the study since they had the most up-to-date information. We have referred to the publications from the last 20 years, but focused mainly on the relevant articles published in the last 10 years, with the most attention given to the articles published in the last five years. Other selection factors were the substance, technique, and language utilised to choose the top papers for the study. Systematic reviews and meta-analyses were favoured since they ensured a comprehensive overview of the literature, while also offering extra information on the research issue. The contents were reviewed and classified in the third phase based on the kind of paper, year of publication and relevancy towards different sections of the current manuscript.

\section{Sustainable Mobility}

Sustainable mobility is a universal, effective, clean, and environmentally friendly transportation solution. The current global mobility structure is obviously unsustainable. While transportation does not have its own sustainable development goals (SDGs), it is crucial for achieving other SDGs to achieve targeted growth and development. Countries with the highest SDG scores have more resilient and sustainable mobility measures in place. In contrast, those with the lowest scores are condemned for insufficient transportation infrastructure [22]. The targeted SDGs, either directly or indirectly addressed by sustainable mobility, are presented in Figure 7.

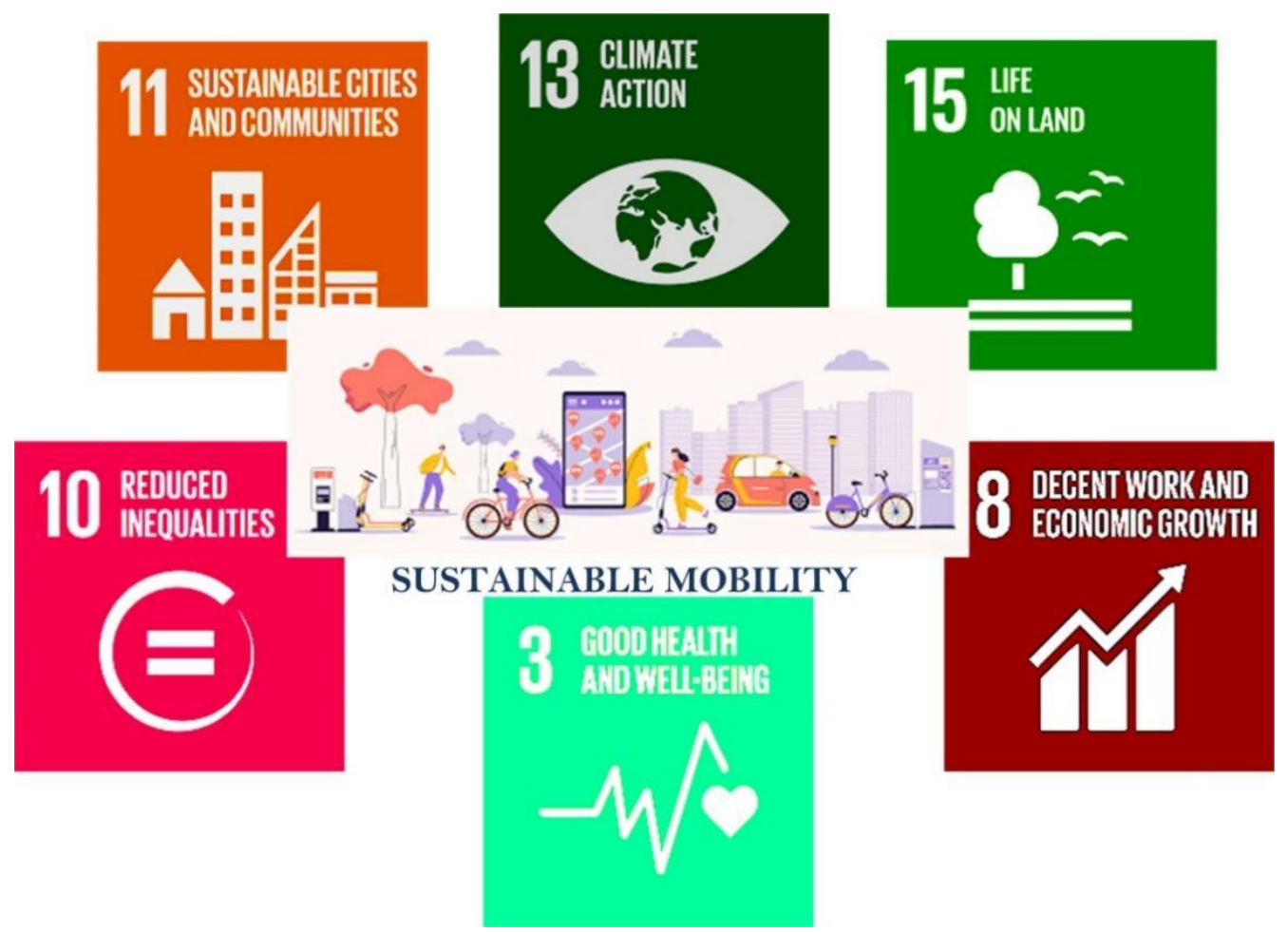

Figure 7. Targeted SDGs addressed by sustainable mobility. 
Sustainable mobility is originated from the wider definition of "sustainable development", which is described as "development that meets current needs without jeopardising the ability of future generations to meet their own needs" [23]. The broad benefits of sustainable mobility $[24,25]$ are depicted in the infographic (Figure 8), which include energy security, economic growth, environmental sustainability, and improved quality of life.

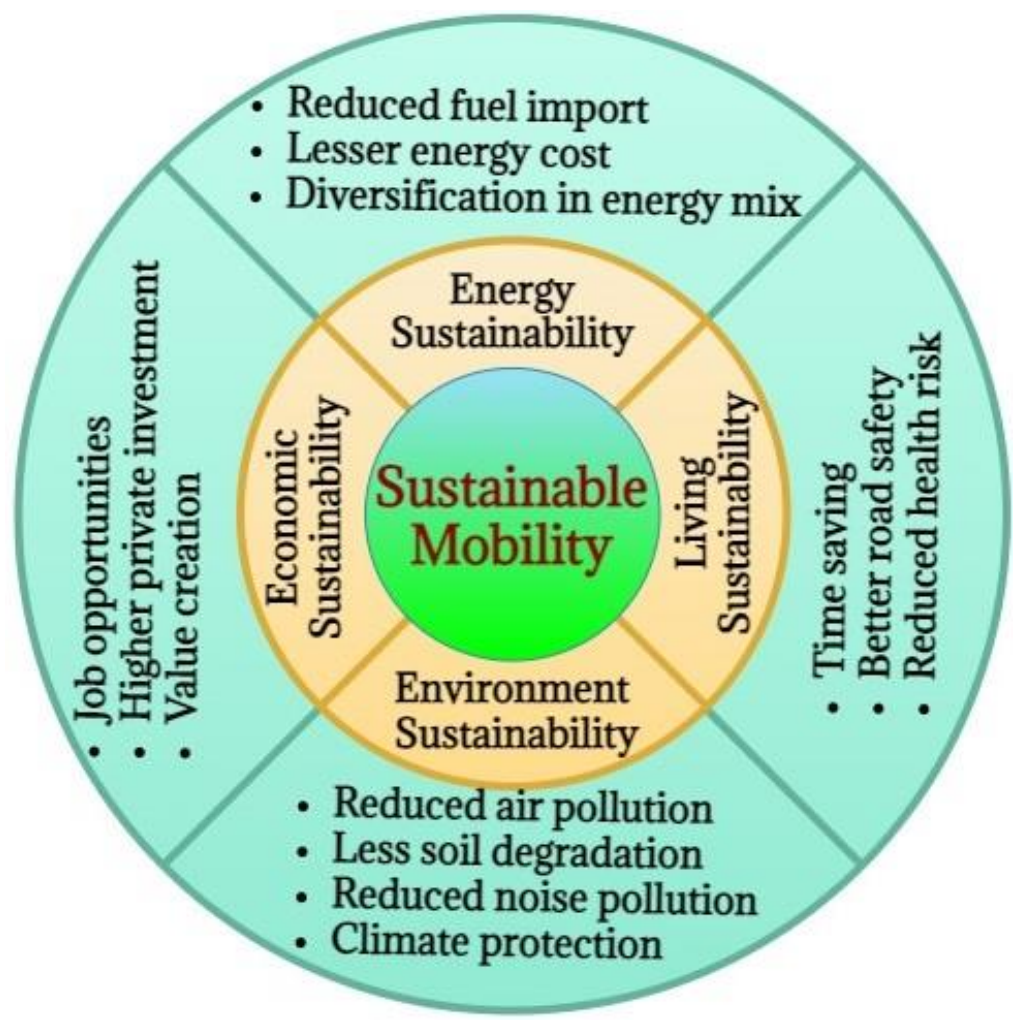

Figure 8. Benefits of sustainable mobility.

Several studies on sustainable mobility can be found in the literature; restricting ourselves to the most recent ones, we refer to [26-40]. Klecha and Gianni [26] investigated the role of technology in fostering a change in behaviour towards sustainable transportation. Some investigations on sustainable mobility are tabulated in Table 1.

Table 1. Investigations on sustainable mobility.

\begin{tabular}{|c|c|c|}
\hline Reference & Year & Research Work \\
\hline Gonzales Aregall et al. [27] & 2018 & $\begin{array}{l}\text { Green port techniques for mitigating negative externalities in the } \\
\text { countryside were studied. }\end{array}$ \\
\hline Ranieri et al. [28] & 2018 & Reviewed creative last-mile logistics solutions. \\
\hline Taiebat et al. [29] & 2018 & Reviewed the effects of automated vehicles on long-term mobility. \\
\hline Ferrero et al. [30] and Santos G [31] & 2018 & Reviewed shared mobility. \\
\hline Biresselioglu et al. [32] & 2018 & Investigated electric mobility. \\
\hline Letnik et al. [33] & 2018 & $\begin{array}{l}\text { Discussed the policies and measures that need to be adopted for } \\
\text { sustainable, energy-efficient urban transportation. }\end{array}$ \\
\hline Pojani and Stead [34] & 2018 & Policy design for sustainable urban transport. \\
\hline Martinez-Diaz et al. [35] & 2019 & Future of autonomous driving. \\
\hline Lopez et al. [36] & 2019 & $\begin{array}{c}\text { Technological advancements in bus transportation and their effect on } \\
\text { environmental and social sustainability. }\end{array}$ \\
\hline Tirachini, A [37] & 2019 & Travel behaviour and sustainable mobility. \\
\hline Holden et al. [38] & 2019 & Aspects of sustainable mobility at 2030 . \\
\hline Ren et al. [39] & 2020 & Review of Green and Sustainable Logistics. \\
\hline Kumar, R.R. and Alok K [40] & 2020 & Prospects for sustainability. \\
\hline
\end{tabular}


Scientists, transportation specialists, local government officials, and researchers from various organisations have developed a few techniques for evaluating the efficiency and cost-effectiveness of sustainable urban mobility initiatives, which are used to determine the most effective measures and their economic advantages [41,42]. In Portugal, the primary focus for building sustainable urban transportation strategies has changed to achieving social and economic advantages [43].

The diverse variety of particular goals of urban transportation should address the environmental, social and economic components of sustainability. The components mentioned above are closely interconnected to one another, and the most often discussed one is environmental aspects. Environmental aspects are achieved by minimising travel-trip replacement, distance (e.g., merging residential and retail functions), shifting modes (e.g., cutting private automobile usage, encouraging cycling and multimodality), and decarbonisation (e.g., zero or low-emission transportations) [44,45]. Policymakers are addressing these issues in order to meet the assumptions of better city decarbonisation [44]. One of them is the sharing economy, which entails both sustainable resource management and efficient asset management. Presently, more than $70 \%$ of Europeans live in cities, and the economy as a whole loses 1\% of GDP each year due to traffic congestion; hence, urban mobility must be optimized [46]. According to Tilley and Houston [47], social and demographic changes may have a significant impact on mobility trends, particularly in urban and suburban regions. There may be a variety of reasons that drives such a tendency and the environmental views of urban dwellers, particularly young people [48]. Young adults were enthusiastic about the advent of recent mobility services, such as Uber and similar solutions, often known as Mobility-as-a-Service (MaaS) [49-52]. The increased popularity of MaaS in metropolitan cities may lead to changes in young people's mobility choices.

The following sections are focused on environmental, socio-economic and technological aspects of sustainable mobility. Some of the impacts of sustainable mobility overlap in socio-economic-environmental previews. Such impacts are discussed where they are more suitable, and discussions are limited to recent literature to cope with the recent trends.

\section{Environmental Aspects}

Environmental conservation is a major focus and concern of sustainable mobility policies; in some cases, it is described solely as mobility that reduces environmental consequences. Even if this definition is incorrect, eliminating pollutants and greenhouse gases is the primary goal of most interventions to create sustainable mobility. Korshunova et al. [53] explored sustainable mobility in the context of humanization in Belarus, Russia's urban environment. Their research took into account future generations' interests and found that "sustainable mobility" represents human freedom in spatial movement that does not impair the environment or the health of others. Papantoniou et al. [54] explored the sustainable mobility elements of university campuses. In this regard, policymakers must analyse students' mobility, particularly their travel habits, in order to identify priority measures for promoting sustainable mobility. Attard et al. [55] concentrated on the services in a university campus situated on the Island of Malta's metropolitan agglomeration. According to their findings, shared demand responsive transport (DRT) services can deliver mobility solutions that assist the adoption of green solutions for sustainable campuses.

This section is broadly divided into two subsections. Section 4.1 discusses the air pollution and global warming caused by transportation and the associated human health effects. It also discusses evident pieces of literature on the reduction in pollution from adopting sustainable transportation. In Section 4.2, the issue of noise pollution is investigated, and potential prevention and reduction approaches are discussed.

\subsection{Air Pollution and Emission of GHG}

The most significant pollutants emitted by transportation are: $\mathrm{PM}_{10}$ and $\mathrm{PM}_{2.5}$ (particulate matter), $\mathrm{NO}_{2}$ (nitrogen dioxide), $\mathrm{O}_{3}$ (ozone), $\mathrm{BaP}$ (benzo [a] pyrene), $\mathrm{SO}_{2}$ (sulphur 
dioxide), $\mathrm{CO}$ (carbon monoxide), and benzene [56]. The consequences for human wellbeing are enormous, as tabulated in Table 2.

Table 2. Premature deaths owing to exposure to $\mathrm{PM}_{2.5}, \mathrm{NO}_{2}$ and $\mathrm{O}_{3}$ (2018).

\begin{tabular}{ccc}
\hline Pollutant Name & Premature Deaths in Europe & Premature Deaths in EU28 \\
\hline $\mathrm{PM}_{2.5}$ & $417 \mathrm{k}$ & $379 \mathrm{k}$ \\
$\mathrm{NO}_{2}$ & $55 \mathrm{k}$ & $54 \mathrm{k}$ \\
$\mathrm{O}_{3}$ & $20.6 \mathrm{k}$ & $19.4 \mathrm{k}$ \\
\hline
\end{tabular}

$\mathrm{CO}_{2}$, methane $\left(\mathrm{CH}_{4}\right)$ and nitrous oxide $\left(\mathrm{N}_{2} \mathrm{O}\right)$ are the primary greenhouse gases released by transportation systems. In 2018, the transportation sector continued to contribute to the most $\mathrm{NO}_{\mathrm{X}}$ emissions (47\% in the EU-28) [56]. Between 1990 and 2014, global CO emissions from transportation increased by $63 \%$ [57]. Transportation-related $\mathrm{CO}_{2}$ emissions have risen at a faster rate than any other sector over the last 50 years, accounting for $23 \%$ of global energy-related $\mathrm{CO}_{2}$ emissions in 2014 [58]. In 2015, international and domestic aviation accounted for $10 \%$ of transportation $\mathrm{CO}_{2}$ emissions, land freight (road and rail) accounted for $28 \%$, and sea and air freight accounted for $12 \%$ [59].

Emissions are one of the most significant external factors of the transportation industry, wreaking havoc on the environment as well as the health of those exposed. The elimination of pollution is at the core of most policies supporting sustainable mobility. Because of improvements in productivity, electrification, and expanded use of bio-fuels, global transportation emissions increased by $<0.5 \%$ in 2019 , compared to $1.9 \%$ since 2000 . Amidst this, transportation nevertheless accounts for $23 \%$ of direct $\mathrm{CO}_{2}$ emissions from fuel combustion [60]. Nocera et al. [61] analysed oscillations in climate change induced by transportation pollution and analysed the economic efficiency of urban mobility interventions that reduce $\mathrm{CO}_{2}$ emissions in their study. They discovered the following $\mathrm{CO}_{2}$ reduction measures: reducing demand for transportation, enhancing the attractiveness of alternative transportation, making private vehicle travel less appealing, information distribution and marketing, reducing the number of municipal and private company fleet vehicles, and smart transportation. EVs minimise GHG emissions by $50-60 \%$ as associated with IC (internal combustion) engines in the EU's current electricity mix [62]. Additional pollution reductions would result from increasing the renewable energy component of the electricity mix. Sustainable mobility removes toxic emissions such as nitrogen oxide, carbon monoxide, sulphur dioxide, hydrocarbons, and particulate matter from vehicle exhaust [63]. Vehicle manufacturing companies play a key role in achieving sustainable mobility. Ford Motor Company's [64] proposal to reduce vehicle emissions is a recent example. Tesla is decreasing not only the overall volume of its emissions but also the amount of pollution produced by each of its vehicles [65]. According to studies, increased modal change from cars to collective transportation has been shown to result in a $20 \%$ reduction in $\mathrm{CO}_{2}$ emissions [66,67].

Target 11.2 of the SDGs calls for the provision of reliable, efficient, open, and sustainable transportation systems. By focusing on accessibility rather than mobility, there are significant opportunities for generating two-way convergence between climate change mitigation action and wider well-being and sustainable development goals in the transportation sector [68].

\subsection{Noise Pollution}

Different transportation sectors such as road, rail, and air transport are the major sources of noise. Road traffic is the primary cause of noise in urban areas. At least one million healthy years of life are lost every year in Western Europe due to transportationrelated environmental noise [69]. Some research works relevant to noise pollution and transportation have been tabulated in Table 3 . 
Table 3. Research works relevant to noise pollution and transportation.

\begin{tabular}{|c|c|c|c|}
\hline Area & Authors & Reference & Research Work \\
\hline \multirow{5}{*}{$\begin{array}{l}\text { Mathematical models } \\
\text { for measure- } \\
\text { ment/predictions of } \\
\text { road traffic noise }\end{array}$} & Garg and Maji, & {$[70]$} & $\begin{array}{l}\text { The authors have given a comprehensive } \\
\text { comparison of the most common traffic noise } \\
\text { models used in industrialised countries. } \\
\text { Technical features such as source modelling and } \\
\text { sound propagation techniques were used to } \\
\text { make the comparison. }\end{array}$ \\
\hline & Khan et al. & [71] & $\begin{array}{l}\text { The authors looked at the literature on air and } \\
\text { noise pollution from urban road traffic, as well } \\
\text { as other factors, including the dispersion models } \\
\text { used, the GIS-based tool used, the geographic } \\
\text { scale of exposure assessment, research location, } \\
\text { sample size, traffic data type, and building } \\
\text { geometry information. They discovered that } \\
\text { deterministic modelling is the most often utilised } \\
\text { evaluation approach for both short-term and } \\
\text { long-term exposure to air and noise pollution. }\end{array}$ \\
\hline & Agarwal and Swami & {$[72]$} & $\begin{array}{l}\text { Under diverse traffic flow conditions, the } \\
\text { authors developed an empirical noise prediction } \\
\text { model for evaluating equivalent noise levels in } \\
\text { terms of equivalent traffic density numbers. }\end{array}$ \\
\hline & Bravo-Moncayo et al. & {$[73]$} & $\begin{array}{l}\text { Using a discrete choice survey in Quito, Ecuador, } \\
\text { the authors calculated the impact of noise } \\
\text { pollution caused by traffic. }\end{array}$ \\
\hline & Sirin & [74] & $\begin{array}{l}\text { Addressed the benefits and drawbacks of } \\
\text { different mathematical models for predicting } \\
\text { pavement noise. }\end{array}$ \\
\hline \multirow{5}{*}{$\begin{array}{l}\text { The effects of noise on } \\
\text { human health }\end{array}$} & Recio et al. & {$[75]$} & $\begin{array}{l}\text { Investigated the long- and short-term links } \\
\text { between road traffic noise and health. }\end{array}$ \\
\hline & Munzel et al. & [76] & $\begin{array}{l}\text { The authors published a review that focused on } \\
\text { the mechanisms and epidemiology of } \\
\text { noise-induced cardiovascular diseases, and it } \\
\text { revealed new information about the mechanisms } \\
\text { underlying noise-induced vascular damage. }\end{array}$ \\
\hline & Sakhvidi et al. & [77] & $\begin{array}{l}\text { According to their study, noise exposure, } \\
\text { primarily from air and road traffic, is linked to } \\
\text { an increased risk of diabetes mellitus. }\end{array}$ \\
\hline & Jafari et al. & [78] & $\begin{array}{l}\text { Their research shows that future neuroimaging } \\
\text { studies to quantify the possible contribution of } \\
\text { noise in predisposing cognitive impairment and } \\
\text { preclinical signs of dementia in humans } \\
\text { are required. }\end{array}$ \\
\hline & $\begin{array}{l}\text { Khosravipour and } \\
\text { Khanlari }\end{array}$ & {$[79]$} & $\begin{array}{l}\text { The authors examined the connection between } \\
\text { myocardial infarction and exposure to road } \\
\text { traffic noise. }\end{array}$ \\
\hline
\end{tabular}


Table 3. Cont.

\begin{tabular}{|c|c|c|c|}
\hline Area & Authors & Reference & Research Work \\
\hline \multirow{6}{*}{$\begin{array}{l}\text { Infrastructures as well as } \\
\text { mitigation techniques }\end{array}$} & Jiang and Kang & [80] & $\begin{array}{c}\text { The authors studied the overall performance of } \\
\text { noise barriers in minimising the environmental } \\
\text { impact of motorways, taking into account their } \\
\text { impacts on reducing noise and visual intrusions } \\
\text { of moving traffic while also potentially causing } \\
\text { visual impact. }\end{array}$ \\
\hline & Ohiduzzaman et al. & [81] & $\begin{array}{l}\text { Investigated noise generation and amplification } \\
\text { mechanisms, as well as various traffic noise } \\
\text { measurement methods and their correlations, as } \\
\text { well as pavement noise abatement, approaches } \\
\text { used by various agencies. }\end{array}$ \\
\hline & Thomas et al. & [82] & $\begin{array}{l}\text { Based on the direction-dependent attenuation of } \\
\text { prior recordings made with a dedicated } \\
\text { 32-channel spherical microphone array, the } \\
\text { authors proposed an auralization technique that } \\
\text { allows an auditive preview of noise abatement } \\
\text { steps for road traffic noise. }\end{array}$ \\
\hline & $\begin{array}{c}\text { Van Renterghem and } \\
\text { Botteldooren }\end{array}$ & [83] & $\begin{array}{c}\text { Investigated and carried out long-term } \\
\text { continuous sound pressure level measurements } \\
\text { along a busy lane. }\end{array}$ \\
\hline & Horne et al. & {$[84]$} & $\begin{array}{c}\text { Authors have compared rounded and sinusoidal } \\
\text { milled rumble strips to reduce roadside } \\
\text { noise emissions. }\end{array}$ \\
\hline & Kleiziene et al. & [85] & $\begin{array}{l}\text { The authors proposed a model for the acoustic } \\
\text { performance of asphalt pavements. }\end{array}$ \\
\hline \multirow[t]{2}{*}{$\begin{array}{l}\text { The reduction of } \\
\text { engine noise }\end{array}$} & Ferrari et al. & [86] & $\begin{array}{l}\text { The authors suggested a closed-loop strategy for } \\
\text { regulating the fuel-injected mass in a Common } \\
\text { Rail diesel engine's combustion chamber. They } \\
\text { demonstrated that the new technology would } \\
\text { significantly reduce } \mathrm{CO}_{2} \text { engine emissions (3\%) } \\
\text { and combustion noise (up to } 0.5 \mathrm{dBA}) \text {. } \\
\text { Substantial fraction reductions in NOx (3\%) and } \\
\text { soot }(6 \%) \text { emissions have also been discovered. }\end{array}$ \\
\hline & Qin et al. & [87] & $\begin{array}{l}\text { The authors presented noise, vibration, and } \\
\text { harshness reduction strategies for various forms } \\
\text { of hybrid electric vehicles (HEVs), as well as } \\
\text { their benefits. }\end{array}$ \\
\hline
\end{tabular}

The aim of transportation policy should be to reduce the population's exposure to noise that is harmful to their health and that causes other forms of trouble. Possible intervention techniques necessitate multidisciplinary expertise, as they must operate on many fronts, from infrastructure and pavement design to mitigation structure design, vehicle noise reduction, and decontamination.

\section{Socio-Economic Aspects}

The importance of transportation in terms of economic growth and human resources cannot be overstated. The way people move to work or enjoy recreation, how companies send workers to reach clients, and how businesses ship goods to distribution centrestransport shapes lives and underpins everything.

The goal of the transportation system should be to advance the excellence of life in the city and suburbs by providing a safe, dependable, integrated, multi-modal, effective, and environmentally friendly transportation system (particularly by employing low / zeroemission cars, park and ride solutions, and so on) [88]. There are various socioeconomic 
facets of sustainable mobility. In addition, some of them also overlap with the environmental or technical categories. Rackwitz et al. [89] investigated income from sustainable transportation systems, job opportunities, and economic growth. Offer et al. [90] studied the relationship between sustainable transportation infrastructure, job development, and economic growth. The progress and commercial research into the potential viability of hydrogen-fuelled vehicles, battery-electric, and hybrid-fuel gas cell plug-ins in the UK's road transportation network are presented in this article. Majumdar et al. [91] evaluated electric vehicle infrastructure's potential economic and environmental consequences in Kolkata public transportation. They discovered that substituting $2 \%$ of the current passenger road transportation mode reduces the amount of fuel and LPG usage each day, demonstrating the viability of constructing parallel electric vehicle infrastructure.

In this section, some socio-economic aspects are addressed in terms of accessibility, pricing, taxes, and incentives.

\subsection{Accessibility}

Accessibility is seen as a helpful notion that may be utilised to create insights into difficulties connected to social exclusion caused by a lack of transportation alternatives. Affordability should be a part of sustainable mobility [92,93]. Several studies have emphasised the importance of transportation equity: An equal distribution of transportation services (infrastructures and transit systems) aids in attaining social justice, with significant implications for health and quality of life [94]. Martens [95] suggested a thorough investigation of equity in transportation development. Beyazit [96] suggested a study of the literature on social impartiality in transportation. Delbosc and Currie [97] suggested using Lorenz curves and the Gini coefficient to measure public transportation equity, which has since been used in many other studies [98-103]. Camporeale et al. [104] considered the importance of fairness and proposed a solution for achieving an equal allocation of transportation impacts (benefits and costs) among consumers. Camporeale et al. [105-107] proposed a methodology for planning and designing public transportation routes that address the demands of cities while promoting equitable access. Gallo [108] suggested a method for improving the price equity of transportation systems. Caggiani et al. [109] concentrated on implementing a cordon-based congestion pricing system on a multimodal network where private vehicles and public transit coexist and included a sensitivity study for a monocentric metropolitan reality by adjusting the scale of the charging area and the volume of the toll.

Attaining equity goals should be one of the transportation policy's guiding standards. Any deal in this field that uses public funds and equity must be included in transportation planning. Sustainable mobility is inherently rational, provided that the poorer social classes often writhe the most from pollution and climate change.

\subsection{Pricing and Taxation}

Pricing may normally be applied to the use of road facilities or car parking. A toll is levied on car drivers for the use of a single piece of arrangement or for accessing a certain part of a city, and the driver is responsible for paying for parking. In terms of sustainable mobility, the policies seek to raise the relative costs of private vehicle usage in order to encourage a modal break in favour of other means of transportation, such as mass transportation, cycling, and walking. Often, road pricing has a straight environmental implication, discriminating prices based on the vehicle's environmental compatibility [110-112]. In order to achieve competitive mobility, road pricing should be closely related to the principle of external costs [113]; in fact, the best road pricing should be that which is capable of charging the car user with all of the external costs it generates [114,115]. Indeed, optimal pricing is not feasible from this perspective, and parking pricing and road pricing strategies are still regarded as second-best approaches [116].

Taxation policies on fuels or car ownership are commonly used in Western countries, distinguished from environmental effects and greenhouse gas emissions. Santos [117] 
calculated and compared petrol and diesel taxes for 22 European countries, taking into account the impact of fuel taxation on fuel efficiency. Steinsland et al. [118] investigated the climate, financial, and equity implications of a fuel tax, a road toll, and a commuter tax credit. According to the research by Montag [119], fuel taxes are the primary tool for reducing automotive emissions. Using data from the US airline industry, Fukui \& Miyoshi [120] investigated the impact of an increase in aviation fuel tax on cuts in fuel usage and carbon emissions.

\subsection{Incentives}

The use of various sorts of incentives in transportation systems to develop sophisticated transportation congestion management solutions has recently received a lot of attention. Rather than employing assumed or fixed-amount rewards, Xiong et al. [121] examined integrated and individualised passenger information and suggested an incentive strategy to encourage more energy-efficient travel and mobility decisions. Herradoe et al. [122] proposed the idea of "incentivized sustainable mobility" that encompasses four stakeholders: residents, municipalities, commerce, and mobility services. According to the investigations of Ricci et al. [123], incentive-based strategies might promote the adoption of sustainable transport. Their research lays the groundwork for creating sophisticated algorithms capable of tracking mobility and incentivizing people's habits concerning sustainable mobility. Some literature on the incentive approaches in transportation systems is tabulated in Table 4.

Table 4. Literature on the incentive approaches in transportation systems.

\begin{tabular}{|c|c|c|}
\hline Authors & Reference & Research Work \\
\hline Semanjski et al. & [124] & $\begin{array}{l}\text { The authors have explored the role of smartphones as mobility } \\
\text { behaviour sensors, as well as the responsiveness of various } \\
\text { attitudinal profiles to customised route recommendation incentives } \\
\text { supplied via mobile phones. Their findings demonstrate which user } \\
\text { profiles are most likely to accept such incentives. }\end{array}$ \\
\hline Xie et al. & {$[125]$} & $\begin{array}{l}\text { The authors have investigated different demographic segments' } \\
\text { perceptions of incentives and timetable delays to investigate } \\
\text { sustainable mobility. }\end{array}$ \\
\hline Kacperski and Kutzner & {$[126]$} & $\begin{array}{c}\text { The authors have discovered that financial and symbolic incentives } \\
\text { encourage 'green' charging decisions. }\end{array}$ \\
\hline Pianese et al. & {$[127]$} & $\begin{array}{l}\text { The authors have developed a unique external incentive system } \\
\text { based on a verifiable third party with the purpose of encouraging } \\
\text { long-term sustainability by changing the profit margins for } \\
\text { proof-of-work contributors without choking the transaction rate. }\end{array}$ \\
\hline Storch et al. & [128] & $\begin{array}{l}\text { According to their findings, even a minor increase in financial } \\
\text { incentives may significantly influence specific user groups' } \\
\text { ride-sharing acceptance. }\end{array}$ \\
\hline Tian et al. & [129] & $\begin{array}{l}\text { The authors have defined preferred users of an incentive-based traffic } \\
\text { demand management method. They proposed incentive-based traffic } \\
\text { demand management (IBTDM), which gives monetary incentives to } \\
\text { commuters to change their departures geographically or temporarily } \\
\text { in order to alleviate congestion. }\end{array}$ \\
\hline Fisher et al. & [130] & $\begin{array}{l}\text { The authors have investigated how place making and positive } \\
\text { incentives may improve urban walkability and revolutionise citizens' } \\
\text { perceptions of streets as public spaces. They discussed the operations } \\
\text { of the EMPOWER project, which began in May } 2015 \text { to gather } \\
\text { evidence on the power of positive incentives and social innovation to } \\
\text { promote sustainable transportation. }\end{array}$ \\
\hline
\end{tabular}


Table 4. Cont.

\begin{tabular}{ccc}
\hline Authors & Reference & Research Work \\
\hline Eshtiaghi et al. & {$[131] \quad \begin{array}{c}\text { The authors worked on analytic network methodology, and } \\
\text { identified and prioritised the elements that influence the adoption of } \\
\text { electric cars. In comparison to other criteria, their findings revealed } \\
\text { that economic variables had the most significant influence. The most } \\
\text { important factors in each criterion were depreciation time, } \\
\text { production firm, fuel subsidy, availability of repair shop, automobile, } \\
\text { and relevance to the environment. }\end{array}$} \\
Yongling and Mingming & $\begin{array}{c}\text { The authors used duopoly analysis to look into the impact of } \\
\text { incentives on the uptake of electric vehicles under subsidy } \\
\text { programmes. They discovered that extended driving range might } \\
\text { inhibit EV adoption and suggested that the government raise its } \\
\text { subsidies for a longer-range EV. }\end{array}$ \\
\hline
\end{tabular}

Government subsidies play a vital role in the adoption of sustainable transportation [133-136]. Zhang and Huang investigated the vehicle product-line strategy in the context of government subsidy schemes for electric/hybrid automobiles [133]. Ouyang et al. [134] examined the entire cost of owning an electric car in China in the post-subsidy period. They discovered that the elimination of the buying subsidies, as well as the proliferation of COVID-19, had a substantial impact on Chinese customers' purchasing intentions for EVs. Their findings indicate that tiny BEVs will attain parity before 2025, but medium and large BEVs will do so by 2030. They discovered that incentive programmes have a large influence and that oil prices are expected to considerably influence the time it takes for EVs to achieve parity. As a result, policymakers should implement incentive programmes to ensure a seamless transition to China's vehicle fleet electrification. Li et al. [135] investigated the influence of the Chinese government's subsidy plan for hydrogen filling stations on the market dissemination of hydrogen fuel cell cars (HFCVs). Their model suggests that the dynamic subsidy mode, which is based on an experience weighted attraction method, outperforms the static subsidy mode. They discovered that selecting an effective first subsidy scheme can improve HFCV sales by about $40 \%$. Their findings reveal that early government intervention in establishing first HRSs can boost market diffusion efficiency by more than $76.7 \%$.

\section{Technical Aspects}

This section focuses on the key subjects linked to technical solutions created to improve sustainable transportation. The following section focuses on the primary sustainable fuel vehicles (SFVs) currently employed in the automobile industry. Enormous effort has been put into developing new fuels and engines that can cut air pollution. In recent years, the automobile industry has boosted the manufacture of alternative fuel vehicles (AFVs) fuelled by electricity, natural gas, and hydrogen, because they create less of a carbon footprint and have the potential to boost vehicle fuel efficiency. All AFVs are not sustainable fuel vehicles, but all SFVs are AFVs in the present era. In this section, AFVs are discussed, which are SFVs. Alternative fuelling stations in the U.S.A by 2019 are presented in Figure 9.

Technology advancements and government assistance programmes have already raised the demand for alternative fuel vehicles (AFVs) [137]. According to Kamila and Masaru, a government subsidy for AFVs might enhance the public image and may support an increase in AFV market penetration rates [138]. The following major forms of sustainable fuel vehicles, as depicted in Figure 10, are currently the most promising and employed in road transportation [139]. 


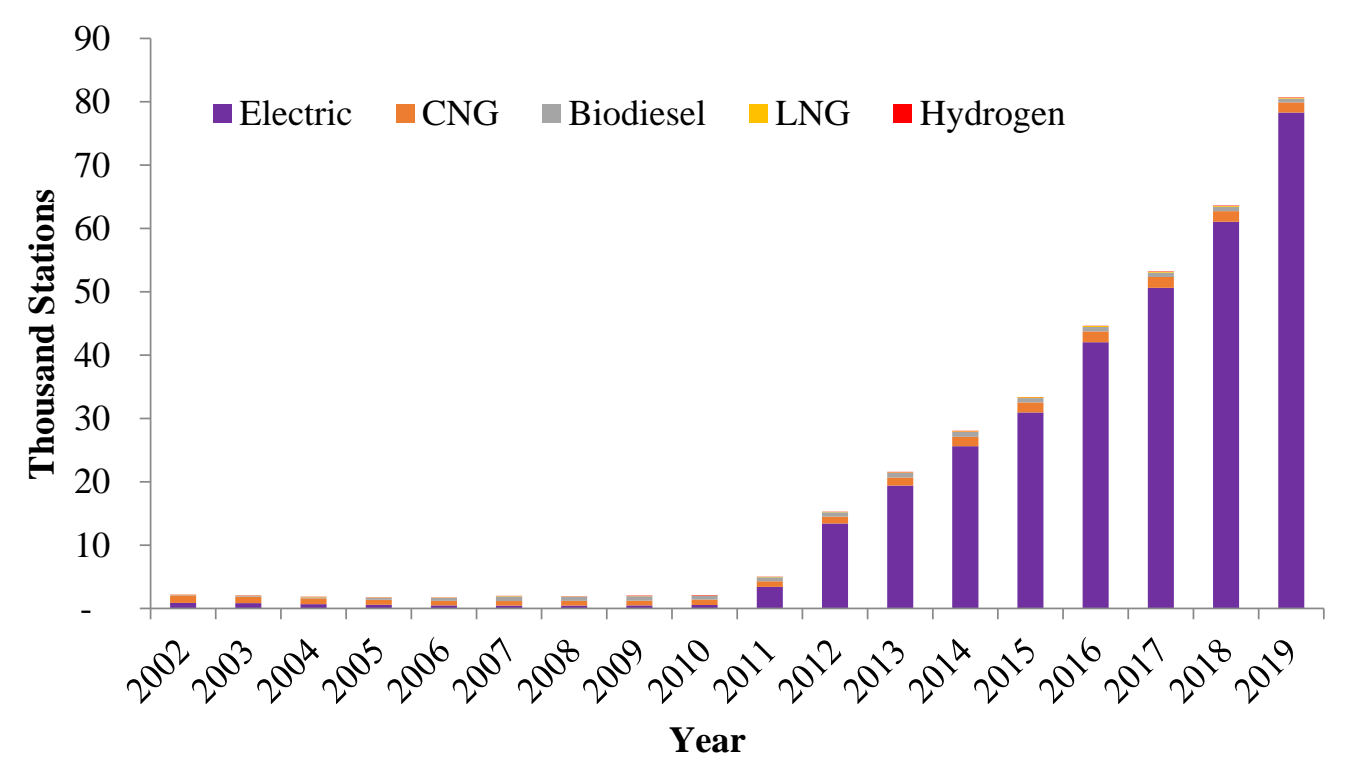

Figure 9. Alternative fuelling stations in the USA. Data collected from Ref. [136].

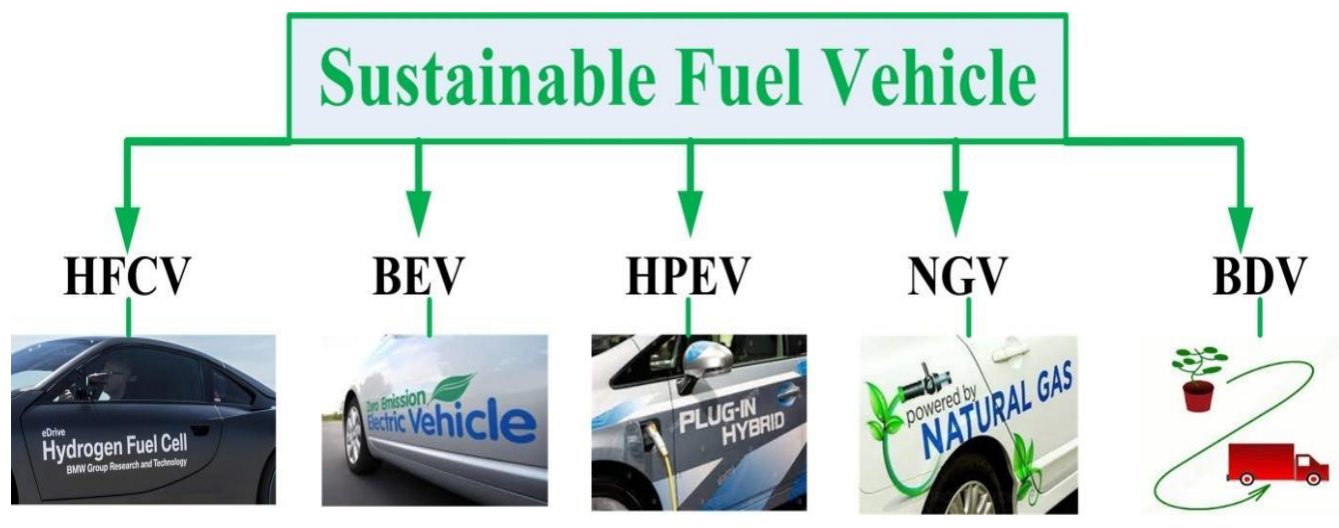

Figure 10. Different types of commercialized SFV.

The strength and shortcomings of different types of commercialized SFV are presented in Table 5.

Grid load management control may become increasingly important as the number of EVs on the road rises, resulting in higher energy consumption [206]. This problem has been addressed using the vehicle-to-grid (V2G) technology [207], which is based on returning battery collected energy to be dispersed in the grid in order to minimise total energy requirements from the primary source. However, in order to offer effective energy service to the grid, management techniques are necessary to improve the energy distribution process during the day [208]. Finally, a developing charging method on electrified highways is the inductive charging system, which permits battery charging while driving [209]. In 2018, Sweden's first electrified road, dubbed eRoadArlanda, opened to recharge electric cars by transmitting electricity from a road-rail [210]. Hydrogen is a promising technology for the future mobility sector, and the post-COVID 19 era is a transition to the hydrogen era [21]. 
Table 5. Comparison of the strengths and shortcomings of each SFV model.

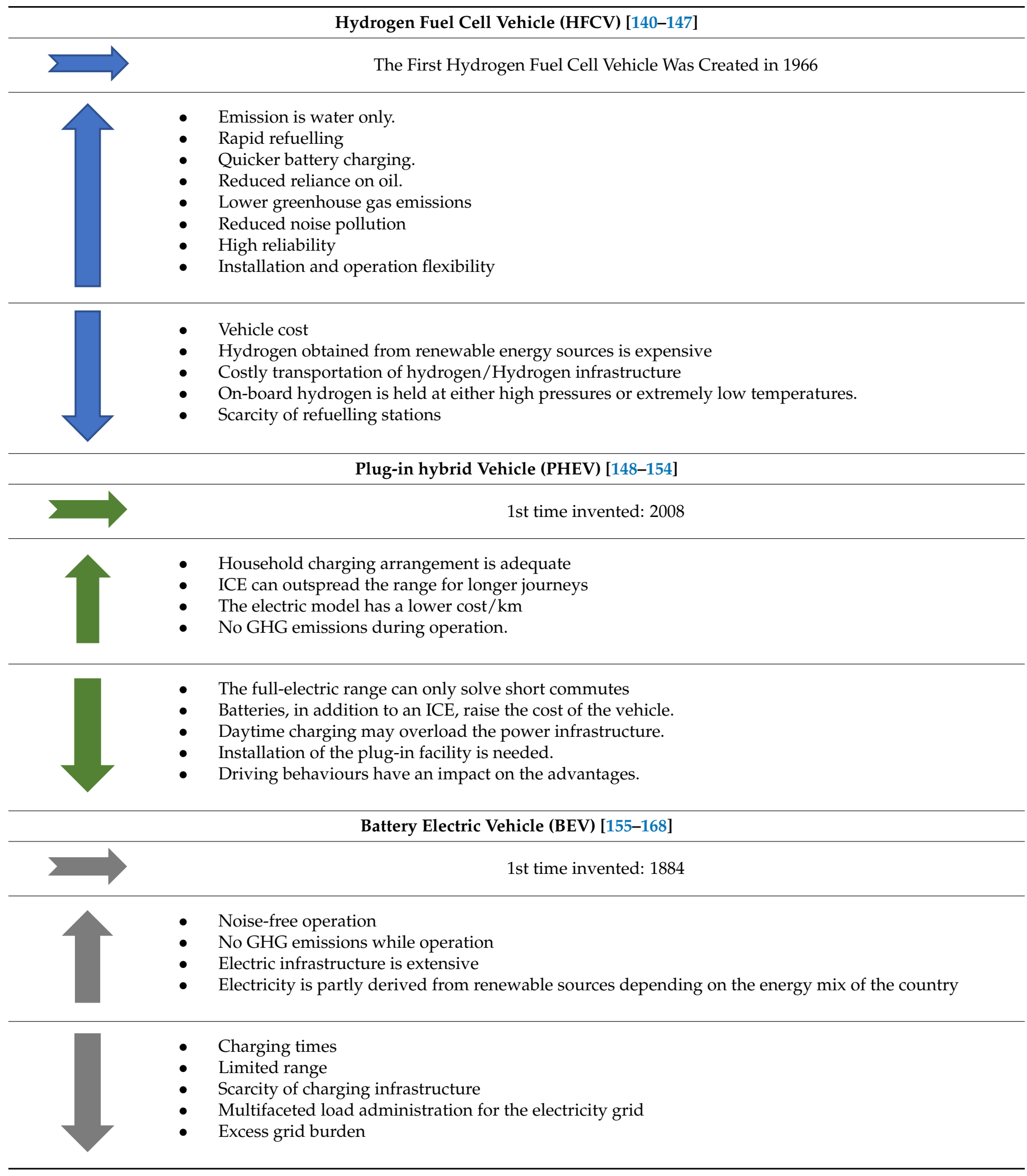


Table 5. Cont.

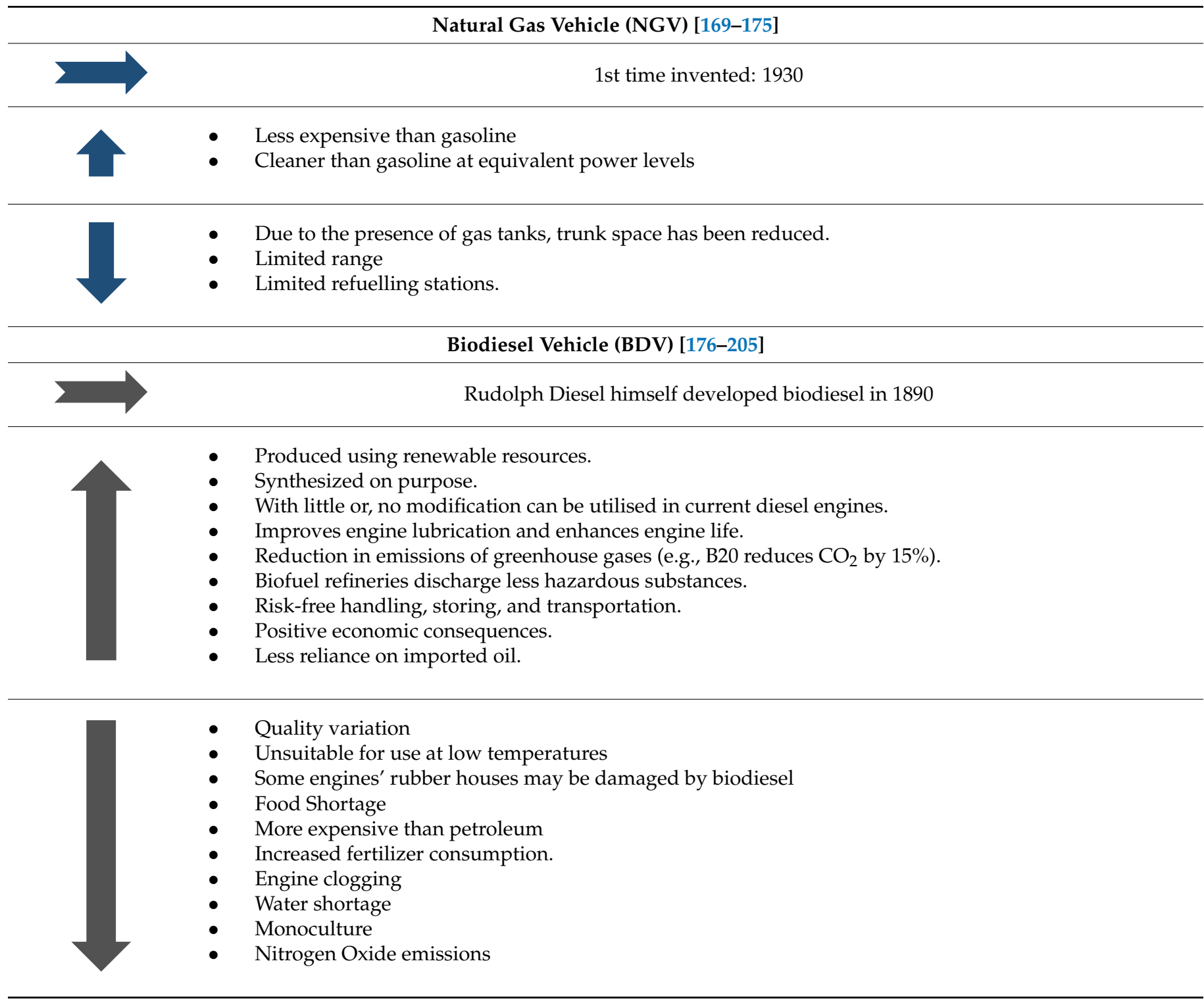

\section{Approaches}

Different approaches to implementing sustainable mobility are discussed in this section. New solutions for people's mobility have mostly been observed in cities. Among these options are free-floating and station-based car-sharing systems [211], an integrated passenger transportation system and shipping tariff [212], bus rapid transit, fare management integration, payment system integration, smart cards systems, bike-sharing systems [213], bus priority (dedicated lanes), cycling, the expansion of pedestrian infrastructure [214,215], free-fare public transportation [216], and many more alternatives. Different approaches to sustainable mobility proposed by researchers are tabulated in Table 6.

Different sustainable mobility approaches, such as shared mobility services, the promotion of cycling, walking, public transport, green transports and eco-driving are presented in Figure 11. 
Table 6. Different approaches to sustainable mobility.

\begin{tabular}{|c|c|c|}
\hline Reference & Proposed Approach & Location \\
\hline [211] & $\begin{array}{l}\text { - Car-sharing systems that are free-floating and } \\
\text { station-based }\end{array}$ & Romania \\
\hline [212] & - Car-sharing and an integrated passenger transit system & Switzerland \\
\hline$[213]$ & $\begin{array}{ll}\text { - } & \text { Rapid bus transit } \\
\text { - } & \text { Integration of fare management and payment systems } \\
\text { - } & \text { Smart card systems } \\
\text { Bike-sharing schemes }\end{array}$ & Zagreb and its Surrounding Area \\
\hline
\end{tabular}

$[214,215]$

- Dedicated lanes for different mobility approaches

- Cycling

- Expansion of pedestrian infrastructure

Paris, Mediterranean Partner Countries (MPCs)

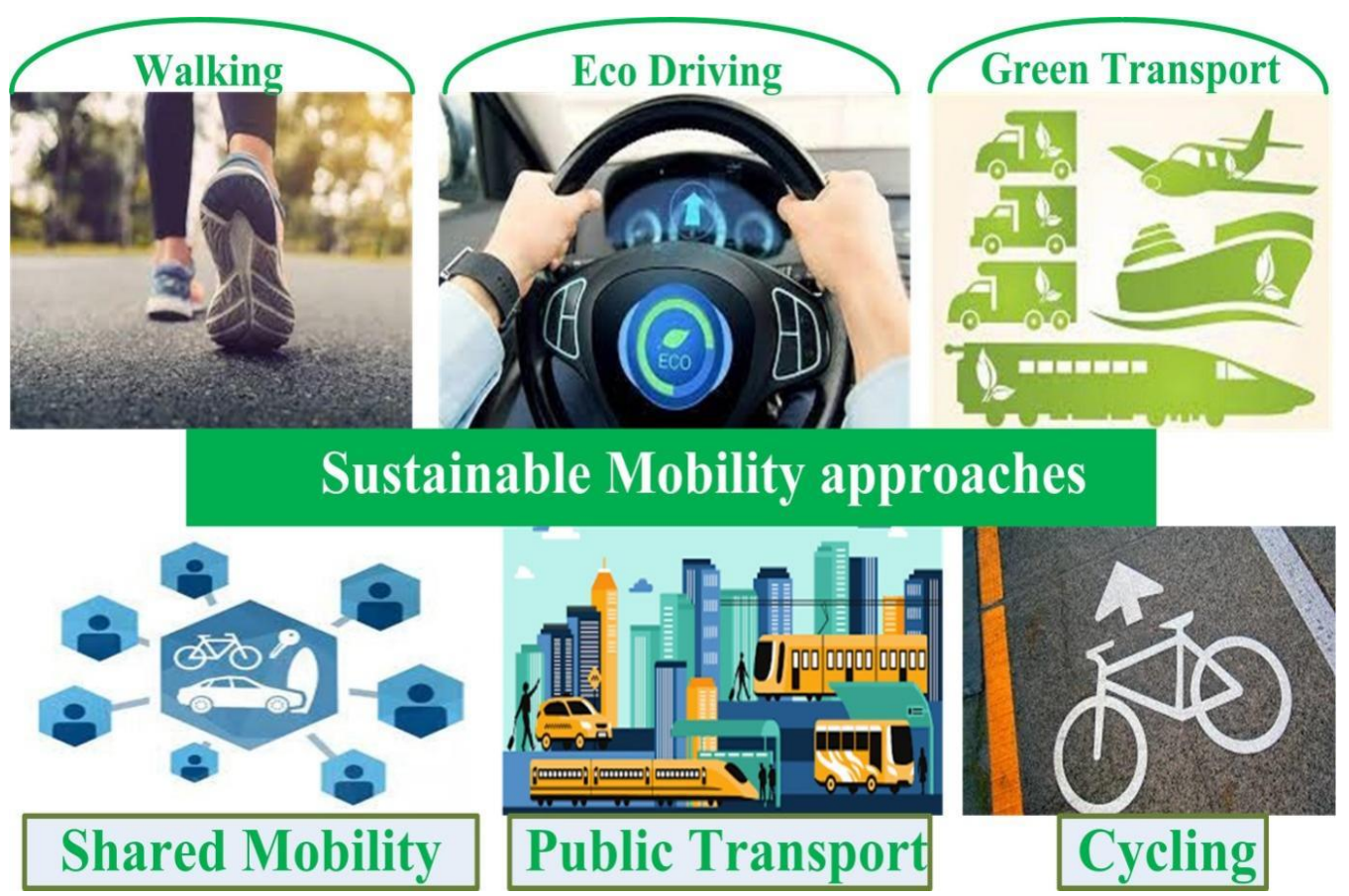

Figure 11. Different sustainable mobility approaches.

\subsection{Shared Mobility Services, Public Transportation and Eco-Driving}

Over the last few decades, the idea of shared mobility services has evolved in terms of how to incorporate them into urban transportation networks and make them more efficient from a social, economic, and environmental standpoint [217,218]. Shared mobility will result in substantial changes in a short period and at a low cost of technology [219]. Furthermore, shared mobility services are transforming the conventional transportation business. They have the disruptive possibilities to craft a transition toward social, environmental, and economic efficiency by applying technologies [217]. New shared mobility networks, on the other hand, may have both advantages and disadvantages. In terms of optimistic 
externalities, new ways of taxation could raise new tax revenue from new services. The usage of statistical data by emerging mobility providers, on the other hand, is at the heart of market control $[218,220]$. Shared mobility's negative externalities vary depending on the service model, local characteristics, and time of day. The influence of vehicle sharing, the portrayal of user characteristics, and the knowledge of adoption barriers in various situations have all been studied extensively, with the bulk of studies focusing on personal motives and the system's consumer-demand feasibility [221-223]. With growing pressure on car-sharing productivity, there is a greater need for new and innovative solutions.

Inturri et al. [224] describe the instance of Catania, a medium-sized city (300,000 people) in southern Italy, where university students enjoy fare-free public transportation (FFPT). They discovered that FFPT for students goes beyond mobility difficulties and may be viewed as a University of Catania social policy aiming at increasing the welfare and wellbeing of its students. They found a significant influence of this policy on student behaviour, paving the way for future stages in which continuous monitoring of PT level of service, along with student experience, will be critical to improving PT and promoting a paradigm shift in transportation. Inturri et al. [225] used a spatial and statistical method to establish meaningful and easy indicators for sustainable mobility planning by investigating the association between PT usage, user satisfaction, and PT accessibility. Eco-driving is another modern approach that tries to reduce GHG emissions in the existing vehicle infrastructure through efficient fuel use.

\subsection{Promotion of Cycling and Walking}

The encouragement of walking and cycling, known as "soft mobility", is one of the most frequent forms of sustainable mobility in urban environments [226-228]. This approach has a huge societal advantage in terms of healthy living [229-232]. Physical activity was found to be favourably linked with total walkability and residential density by Van Dyck et al. [233,234]. Other research $[235,236]$ has discovered favourable links between the built environment and emotional wellbeing, as well as life satisfaction. In a Swedish study, Sundquist et al. [237] looked at moderate to vigorous physical activity and discovered a link between frequency of physical activity and community walkability. Blečić et al. [238] conducted an assessment of operational approaches for analysing walkability. Their study provides decision-making aids for environmentally conscious planning and urban design. Urban planning and design that is focused on pedestrians-paying attention to their requirements, habits, and perceptions-is gaining popularity among academics, practitioners, and public policymakers interested in sustainability [239-246]. The literature on this entire topic is vast; we have reffered to a few generic publications that help us better understand the individual themes [247-254].

Following these steps and policies can promote pedestrian mobility:

- Maintenance and repair of sidewalks,

- Construction of underpasses and overpasses or marked and lit pedestrian crossings, and

- Construction of movable infrastructure to aid pedestrian movements.

The following are the primary policies that encourage cycling:

- Construction of bike lanes,

- Preparation of bicycle parking places,

- Incentives for bicycle purchases, and

- $\quad$ Bike-sharing.

Increased non-motorized mode usage, especially when replacing motorised trips, has a number of advantages. The environmental consequences are, of course, only if the trip taken by bike or on foot is a replacement for a trip that would otherwise be taken by car.

Freudendal-Pedersen et al. [255] explored how the mobility transformation is intertwined with contemporary society's cultural values, which are profoundly ingrained in the mobile-risk society. They proposed that robust, socially cohesive, and inclusive mobility 
systems that are more than just transportation systems and links are needed to establish viable mobility activities.

\subsection{Policies}

European transportation policy has traditionally prioritised transportation's long-term sustainability. The Transport White Paper [256] lays out the transportation policies for the year 2050. By 2050, the European transport policy seeks to reduce greenhouse gas emissions by $60 \%$. A more recent publication [257] looks at Europe's long-term sustainability, including mobility challenges, until 2030. This document quotes the Action Plan for Low-Emission Mobility [258], which notes, "Low-emission mobility is an integral component of the larger move to the low-carbon, circular economy that is required for Europe to remain competitive and meet the mobility demands of people and goods." The European Commission suggested 20 initiatives for urban areas in the Action Plan on Urban Mobility [259], eight of which are directly related to sustainable mobility on the following topics: plans for sustainable urban mobility; sustainable urban mobility and regional policy; urban transportation and health; sustainable mobility campaigns; energy-efficient driving; lower and zero-emission automobiles; clean and energy-efficient vehicles; internalization of external expenses.

The SUMP (Sustainable Urban Mobility Plan) is given special attention since it is defined as follows: "A Sustainable Urban Mobility Plan is a strategic plan developed to meet the mobility demands of people and companies in cities and their environs for a higher quality of life." It draws on existing planning processes while also taking into account ideas of integration, involvement, and assessment [260]. This planning tool is becoming increasingly popular; over 1100 cities in Europe have developed a SUMP today [261]. In the United States, where there is an overlap of responsibilities and competencies between the federal state and the member states of the union, sustainable mobility is fostered, but in a less organized fashion, as highlighted by [262], which advocated a policy review between 2000 and 2011.

This research shows that European transport policy is geared toward sustainable mobility, with a specific focus on emissions reduction. Furthermore, there is a significant tendency toward eliminating or drastically reducing the use of conventional fuels for passenger and freight transportation, choosing electric mobility for land transport: rail travel in cities and suburbs, and electric or zero-emission automobiles in cities. This trend is predicted to encourage the automotive industry to spend more and more on alternative fuel cars, with a special focus on electric vehicles, in addition to having a significant influence on future mobility patterns. This industrial revolution can already be witnessed today, with an increase in the number of electric and hybrid automobile models on the road, as well as a corresponding increase in market share.

\section{Conclusions, Limitations and Future Research}

This review investigated the selected aspects of sustainable mobility using two decades of research available in the literature from 2001 to 2021. The selected aspects include environmental, economic, and social impacts and technical possibilities. The bibliometric analysis revealed numerous implementable approaches and policy driven-conceivable actions.

The environmental and socio-economic elements demonstrate that sustainable mobility is the potential option for future mobility. The analysis reveals a possibility for using different mobility options that broadly fall under sustainable mobility to fight against the most stressing environmental and socio-economic constraints in transportation. Encouraging walking (given the lower distances within the neighbourhoods/community), cycling (within neighbourhoods and surrounding areas), shared mobility (car-sharing, mass transit, and others), green transportation, eco-driving, and other electric mobility options could help achieve sustainability in the transportation sector. It was also observed that some of the above-highlighted mobility options are already well recognised in climate-concerned countries, and it is time for others to adopt such options. Emerging countries, including the developing and the underdeveloped ones, are also gradually adopting the same options. 
However, it was observed that attaining sustainable mobility is likely the most challenging task among the innumerable challenges associated with the larger picture of achieving sustainable development.

Technology element-based analysis carried out in this review positions the present state of developments in the transport sector as still unsustainable when a thought is given from a lifecycle point of view. Moreover, they are on a sustainable course. Though numerous technology options are available, most of the world's population has been culturally bound to the existing technology options that are unsustainable. Though many current mobility options are unsustainable, the users are quite satisfied with the performance, i.e., fuel use efficiency, mileage, and affordability. The transition to new mobility options would take time and is only possible with the intense policy initiation that benefits the users in all the investigated aspects.

Overall, this research review reveals a clear understanding of what has to be done; it has opened up a question of how to do it. Given the interdisciplinary nature of the stakeholders, each of their opinions about sustainable mobility will be different and more or less confined to their functions and operations. Hence, it may take considerable work to develop acceptable ways to convey it to stakeholders (i.e., raw material providers, manufacturing or production companies and the general public), since the suggested mobility systems and actions must be appreciated even if the outcomes do not match with the expectations of others. Every stakeholder should understand that their fundamental aim is to support a future sustainable mobility system, and that this has to be accomplished. Furthermore, the promotion of efficient, safe, and convenient transportation services, as well as the lowering of urban car traffic and support of low transportation demand, are other vital issues observed from this bibliometric analysis. These observations are quite similar to the existing literature. However, the missing element is the promising technological development toward a future of sustainable mobility. Though we did not deal with this element in detail in this review, our preliminary assessment suggested that hydrogen could be a promising fuel for sustainable mobility, given the limited availability of resources for battery manufacturing.

The authors do acknowledge the limitations of this review. For instance, though there exists a vast literature on this entire topic, we limited our analysis to two decades, mainly referring to a few academic publications, technical reports, and white papers related to environmental, socio-economic and technical aspects of sustainable mobility, along with the different approaches that help us in better understanding the individual themes. Though there are different modes of transport, for instance, on-road and off-road, this review's primary focus was only on sustainable on-road mobility. Additionally, there are a few limitations with the methodological approach we adopted. For example, the data sample can be more extensive due to the broader range of journals and indexing tools, but only limited data are considered in this review; data filtration considering the metrics of relevant and non-relevant citations, is another issue this review did not account for. Based on the limitations and the observations made in this review, the following points can be considered as future research works.

- The selected aspects (environmental, economic, social impact, and technical possibilities) in this review article could be leveraged for other sustainable mobility modes, for instance, water and air transport.

- There is a possibility for cascading impacts on the power sector due to the massive deployment of sustainable mobility systems, especially the electrically operated ones. So, it would be better to discuss the impact on the power grid due to the increased charging demand.

- The impact of sustainable transportation in societal life could be taken up purely from an environmental point of view to understand air quality.

- A key focus could be on policies to promote sustainable mobility considering technological progress. 
We believe the review results may serve as a foundation for assessing the future development of sustainable transportation and would provide a potential lead for sustainable mobility methods. The insight into current paradigms, key areas of research, and the interrelationships amongst the involved fields along with future research options could initiate new research among the practitioners.

Author Contributions: Conceptualization, S.C. and N.M.K.; methodology, S.C.; formal analysis, N.M.K.; investigation, S.C.; resources, S.C., N.M.K. and A.J.; data curation, S.C., N.M.K., A.J., S.K.D. and D.E.; writing—original draft preparation, S.C. and N.M.K.; writing—review and editing, S.C., N.M.K., A.J., S.K.D. and D.E.; visualization, S.C. and N.M.K.; funding acquisition, N.M.K. and A.J. All authors have read and agreed to the published version of the manuscript.

Funding: This research received no external funding.

Institutional Review Board Statement: Not applicable.

Informed Consent Statement: Not applicable.

Data Availability Statement: Not applicable.

Acknowledgments: The authors would like to acknowledge the support received from SusSo Foundation Cares, a Non-profitable Organization (NPO) in India.

Conflicts of Interest: The authors declare no conflict of interest.

\section{References}

1. United Nations. What is the Kyoto Protocol? 2019. Available online: https:/ / unfccc.int/kyoto_protocol (accessed on 5 June 2021).

2. Available online: https://www.ncei.noaa.gov / (accessed on 2 June 2021).

3. Ding, Z.; Jiang, X.; Liu, Z.; Long, R.; Xu, Z.; Cao, Q. Factors Affecting Low-Carbon Consumption Behavior of Urban Residents: A Comprehensive Review. Resour. Conserv. Recycl. 2018, 132, 3-15. [CrossRef]

4. Zhang, J.; Zhang, L.; Qin, Y.; Wang, X.; Zheng, Z. Impact of Residential Self-Selection on Low-Carbon Behavior: Evidence from Zhengzhou, China. Sustainability 2019, 11, 6871. [CrossRef]

5. Available online: https://www.epa.gov/ghgemissions/global-greenhouse-gas-emissions-data (accessed on 2 June 2021).

6. Available online: https://www.climate.gov/news-features/understanding-climate/climate-change-atmospheric-carbondioxide (accessed on 8 June 2021).

7. Available online: https://www.noaa.gov/ (accessed on 1 June 2021).

8. Available online: https://www.who.int/health-topics/air-pollution\#tab=tab_1 (accessed on 3 June 2021).

9. Roadmap to a Single European Transport Area. Available online: https://www.climatepolicydatabase.org/policies/roadmapsingle-european-transport-area (accessed on 1 June 2021).

10. Available online: https://www.iea.org/data-and-statistics/charts/global-energy-related-co2-emissions-by-sector (accessed on 15 June 2021).

11. Le Quéré, C.; Jackson, R.B.; Jones, M.W.; Smith, A.J.P.; Abernethy, S.; Andrew, R.M.; De-Gol, A.J.; Willis, D.R.; Shan, Y.; Canadell, J.G.; et al. Temporary Reduction in Daily Global $\mathrm{CO}_{2}$ Emissions during the COVID-19 Forced Confinement. Nat. Clim. Chang. 2020, 10, 647-653. [CrossRef]

12. Saleem, M.A.; Eagle, L.; Low, D. Determinants of Eco-Socially Conscious Consumer Behavior toward Alternative Fuel Vehicles. J. Consum. Mark. 2021, 38, 211-228. [CrossRef]

13. Oliveira, G.D.; Dias, L.C. The Potential Learning Effect of a MCDA Approach on Consumer Preferences for Alternative Fuel Vehicles. Ann. Oper. Res. 2020, 293, 767-787. [CrossRef]

14. García-Melero, G.; Sainz-González, R.; Coto-Millán, P.; Valencia-Vásquez, A. Sustainable Mobility Policy Analysis Using Hybrid Choice Models: Is It the Right Choice? Sustainability 2021, 13, 2993. [CrossRef]

15. Apostolou, D.; Xydis, G. A literature review on hydrogen refuelling stations and infrastructure. Current status and future prospects. Renew. Sustain. Energy Rev. 2019, 113, 109292. [CrossRef]

16. Falcone, P.M.; Hiete, M.; Sapio, A. Hydrogen Economy and Sustainable Development Goals (SDGs): Review and Policy Insights. Curr. Opin. Green Sustain. Chem. 2021, 31, 100506. [CrossRef]

17. Staffell, I.; Scamman, D.; Velazquez Abad, A.; Balcombe, P.; Dodds, P.E.; Ekins, P.; Shah, N.; Ward, K.R. The Role of Hydrogen and Fuel Cells in the Global Energy System. Energy Environ. Sci. 2019, 12, 463-491. [CrossRef]

18. Dincer, I. Covid-19 Coronavirus: Closing Carbon Age, but Opening Hydrogen Age. Int. J. Energy Res. 2020, $44,6093-6097$. [CrossRef] [PubMed]

19. Bicer, Y.; Dincer, I. Comparative life cycle assessment of hydrogen, methanol and electric vehicles from well to wheel. Int. J. Hydrogen Energy 2017, 42, 3767-3777. [CrossRef] 
20. Apostolou, D.; Welcher, S.N. Prospects of the Hydrogen-Based Mobility in the Private Vehicle Market. A Social Perspective in Denmark. Int. J. Hydrogen Energy 2021, 46, 6885-6900. [CrossRef]

21. Apostolou, D.; Enevoldsen, P.; Xydis, G. Supporting Green Urban Mobility—The Case of a Small-Scale Autonomous Hydrogen Refuelling Station. Int. J. Hydrogen Energy 2018, 44, 9675-9689. [CrossRef]

22. Available online: https:/ / www.sum4all.org/implementing-sdgs (accessed on 25 May 2021).

23. World Commission on Environment and Development. Our Common Future; Oxford University Press: Oxford, UK, 1987.

24. Available online: https:/ / www.transformative-mobility.org/publications/benefits-of-sustainable-mobility (accessed on 11 June 2021).

25. Mealha, Ó.; Divitini, M.; Rehm, M. (Eds.) Systems and Technologies 80; Springer: Cham, Switzerland, 2018; pp. 137-149.

26. Klecha, L.; Gianni, F. Designing for Sustainable Urban Mobility Behaviour: A Systematic Review of the Literature. In Citizen, Territory and Technologies: Smart Learning Contexts and Practices, Smart Innovation; Springer: Cham, Switzerland, 2017; pp. 137-149.

27. Gonzales Aregall, M.; Bergqvist, R.; Monios, J. A global review of the hinterland dimension of green port strategies. Transp. Res. D 2018, 59, 23-34. [CrossRef]

28. Ranieri, L.; Digiesi, S.; Silvestri, B.; Roccotelli, M. A Review of Last Mile Logistics Innovations in an Externalities Cost Reduction Vision. Sustainability 2018, 10, 782. [CrossRef]

29. Taiebat, M.; Brown, A.L.; Saord, H.R.; Qu, S.; Xu, M. A Review on Energy, Environmental, and Sustainability Implications of Connected and Automated Vehicles. Environ. Sci. Technol. 2018, 52, 11449-11465. [CrossRef]

30. Ferrero, F.; Perboli, G.; Rosano, M.; Vesco, A. Car-sharing services: An annotated review. Sustain. Cities Soc. 2018, 37, 501-518. [CrossRef]

31. Santos, G. Sustainability and Shared Mobility Models. Sustainability 2018, 10, 3194. [CrossRef]

32. Biresselioglu, M.E.; Kaplan, M.D.; Yilmaz, B.K. Electric mobility in Europe: A comprehensive review of motivators and barriers in decision making processes. Transp. Res. Part A Policy Pract. 2018, 109, 1-13. [CrossRef]

33. Letnik, T.; Marksel, M.; Luppino, G.; Bardi, A.; Bozicnik, S. Review of policies and measures for sustainable and energy efficient urban transport. Energy 2018, 163, 245-257. [CrossRef]

34. Pojani, D.; Stead, D. Policy design for sustainable urban transport in the global south. Policy Des. Pract. 2018, 1, 90-102. [CrossRef]

35. Martinez-Diaz, M.; Soriguera, F.; Pérez, I. Autonomous driving: A bird's eye view. IET Intell. Transp. Syst. 2019, 13, 563-579. [CrossRef]

36. Lopez, C.; Ruìz-Benitez, R.; Vargas-Machuca, C. On the Environmental and Social Sustainability of Technological Innovations in Urban Bus Transport: The EU Case. Sustainability 2019, 11, 1413. [CrossRef]

37. Tirachini, A. Ride-hailing, travel behaviour and sustainable mobility: An international review. Transportation 2019, 47, 2011-2047. [CrossRef]

38. Holden, E.; Gilpin, G.; Banister, D. Sustainable Mobility at Thirty. Sustainability 2019, 11, 1965. [CrossRef]

39. Ren, R.; Hu, W.; Dong, J.; Sun, B.; Chen, Y.; Chen, Z. A Systematic Literature Review of Green and Sustainable Logistics: Bibliometric Analysis, Research Trend and Knowledge Taxonomy. Int. J. Environ. Res. Public Health 2020, 17, 261. [CrossRef]

40. Kumar, R.R.; Alok, K. Adoption of electric vehicle: A literature review and prospects for sustainability. J. Clean. Prod. 2020, 253, 119911. [CrossRef]

41. Chakhtoura, C.; Pojani, D. Indicator-Based Evaluation of Sustainable Transport Plans: A Framework for Paris and Other Large Cities. Transp. Policy 2016, 50, 15-28. [CrossRef]

42. Haghshenas, H.; Vaziri, M.; Gholamialam, A. Evaluation of Sustainable Policy in Urban Transportation Using System Dynamics and World Cities Data: A Case Study in Isfahan. Cities 2015, 45, 104-115. [CrossRef]

43. Arsenio, E.; Martens, K.; Di Ciommo, F. Sustainable Urban Mobility Plans: Bridging Climate Change and Equity Targets? Res. Transp. Econ. 2016, 55, 30-39. [CrossRef]

44. Diez, J.M.; Lopez-Lambas, M.E.; Gonzalo, H.; Rojo, M.; Garcia-Martinez, A. Methodology for assessing the cost effectiveness of Sustainable Urban Mobility Plans (SUMPs). The case of the city of Burgos. J. Transp. Geogr. 2018, 68, 22-30. [CrossRef]

45. Available online: https://www.ssatp.org/sites/ssatp/files/2018_Annual_Meeting_Abuja/Day1/UTM/Sustainable\%20Urban\% 20Mobility\%20Principles\%20and\%20Planning\%20-\%20Holger\%20Dalkmann.pdf (accessed on 15 July 2021).

46. Ribeiro, J.M.P.; Bocasanta, S.L.; Ávila, B.O.; Magtoto, M.; Jonck, A.V.; Gabriel, G.M.; de Andrade Guerra, J.B.S.O. The adoption of strategies for sustainable cities: A comparative study between Seattle and Florianopolis legislation for energy and water efficiency in buildings. J. Clean. Prod. 2018, 197, 366-378. [CrossRef]

47. Tomanek, R. Free-fare public transport in the concept of sustainable urban mobility. Transp. Probl. 2017, 12, 95-105. [CrossRef]

48. Tilley, S.; Houston, D. The gender turnaround: Young women now travelling more than young men. J. Transp. Geogr. 2016, 54, 349-358. [CrossRef]

49. Suchanek, M.; Szmelter-Jarosz, A. Environmental Aspects of Generation Y's Sustainable Mobility. Sustainability 2019, 11, 3204. [CrossRef]

50. Szmelter, A.; Wo'zniak, H. New Mobility Behaviours and Their Impact on Creation of New Business Models. Torun Bus. Rev. 2015, 15, 79-95.

51. Pick, F.; Dreher, J. Sustaining hierarchy-Uber isn't sharing. Kings Rev. 2015, 8, 1-8.

52. Finck, M.; Ranchordas, S. Sharing and the city. Vanderbilt J. Transnatl. Law 2016, 49, 1299-1369. [CrossRef] 
53. Korshunova, N.N.; Morozova, E.B.; Dolinina, O.E. Sustainable Mobility in the Context of Humanization of the Urban Environment: A Regional Experience. In IOP Conference Series: Materials Science and Engineering; IOP Publishing: Bristol, UK, 2020; Volume 907, p. 012003.

54. Papantoniou, P.; Yannis, G.; Vlahogianni, E.; Attard, M.; Regattieri, A.; Piana, F.; Pilati, F. Developing a Sustainable Mobility Action Plan for University Campuses. Transp. Res. Procedia 2020, 48, 1908-1917. [CrossRef]

55. Attard, M.; Camilleri, M.P.J.; Muscat, A. The Technology behind a Shared Demand Responsive Transport System for a University Campus. Res. Transp. Bus. Manag. 2020, 36, 100463. [CrossRef]

56. Environmental European Agency. Air Quality in Europe-2020 Report; EEA Report No. 09/2020, TH-AL-20-023-EN-N; Publications Office of the European Union: Luxembourg, 2020. [CrossRef]

57. OECD/IEA. $\mathrm{CO}_{2}$ Emissions from Fuel Combustion. 2019. Available online: http://dotstat.oecd.org/?lang=en\# (accessed on 28 May 2021).

58. IPCC. IPCC: Global Warming of 1.5 C. 2018. Available online: https:/ /ipcc.ch/report/sr15/ (accessed on 13 June 2021).

59. ITF. ITF Transport Outlook 2017; OECD Publishing: Paris, France, 2017. [CrossRef]

60. Available online: https:/ / www.iea.org/topics/transport (accessed on 7 June 2021).

61. Nocera, S.; Tonin, S.; Cavallaro, F. Carbon Estimation and Urban Mobility Plans: Opportunities in a Context of Austerity. Res. Transp. Econ. 2015, 51, 71-82. [CrossRef]

62. Moro, A.; Lonza, L. Electricity carbon intensity in European Member States: Impacts on GHG emissions of electric vehicles. Transp. Res. Part D Transp. Environ. 2018, 64, 5-14. [CrossRef] [PubMed]

63. Holden, E.; Banister, D.; Gössling, S.; Gilpin, G.; Linnerud, K. Grand Narratives for sustainable mobility: A conceptual review. Energy Res. Soc. Sci. 2020, 65, 101454. [CrossRef]

64. Ford Motor Company. Sustainability Report 2017/2018, Ford Motor Company. 2018. Available online: https:/ / corporate.ford. com/microsites/sustainability-report-2017-18/customers-products/reducing-emissions/plan.html (accessed on 12 June 2021).

65. Available online: https://www.business-standard.com/article/automobile/elon-musk-should-come-clean-tesla-s-carbonemissions-are-rising-121021801485_1.html (accessed on 7 June 2021).

66. Creutzig, F. Evolving narratives of low-carbon futures in transportation. Transp. Rev. 2015, 36, 341-360. [CrossRef]

67. International Energy Agency. World Energy Outlook 2012; International Energy Agency: Paris, France, 2012; Available online: https:/ / www.oecd-ilibrary.org/energy/worldenergy-outlook-2012_weo-2012-en (accessed on 13 June 2021).

68. Available online: https://www.oecd-ilibrary.org/sites/7dfbd08d-en/index.html?itemId=/content/component/7dfbd08d-en (accessed on 11 June 2021).

69. World Health Organization. Environmental Noise Guidelines for the European Region; WHO Regional Office for Europe: Copenhagen, Denmark, 2018.

70. Garg, N.; Maji, S. A critical review of principal transportation noise models: Strategies and implications. Environ. Impact Asses. 2014, 46, 68-81. [CrossRef]

71. Khan, J.; Ketzel, M.; Kakosimos, K.; Sorensen, M.; Jensen, S.S. Road transportation air and noise pollution exposure assessment-A review of tools and techniques. Sci. Total Environ. 2018, 634, 661-676. [CrossRef]

72. Agarwal, S.; Swami, B.L. Comprehensive approach for the development of transportation noise prediction model for Jaipur city. Environ. Monit. Assess. 2011, 172, 113-120. [CrossRef] [PubMed]

73. Bravo-Moncayo, L.; Pavon-Garcia, I.; Lucio-Naranjo, J.; Mosquera, R. Contingent valuation of road transportation noise: A case study in the urban area of Quito, Ecuador. Case Stud. Transp. Policy 2017, 5, 722-730. [CrossRef]

74. Sirin, O. State-of-the-Art Review on Sustainable Design and Construction of Quieter Pavements-Part 2: Factors Affecting Tire-Pavement Noise and Prediction Models. Sustainability 2016, 8, 692. [CrossRef]

75. Recio, A.; Linares, C.; Banegas, J.R.; Diaz, J. Road transportation noise effects on cardiovascular, respiratory and metabolic health: An integrative model of biological mechanisms. Environ. Res. 2016, 146, 359-370. [CrossRef] [PubMed]

76. Münzel, T.; Schmidt, F.P.; Steven, S.; Herzog, J.; Daiber, A.; Sørensen, M. Environmental noise and the cardiovascular system. J. Am. Coll. Cardiol. 2018, 71, 688-697. [CrossRef]

77. Sakhvidi, M.J.Z.; Sakhvidi, F.Z.; Mehrparvar, A.H.; Foraster, M.; Dadvand, P. Association between noise exposure and diabetes: A systematic review and meta-analysis. Environ. Res. 2018, 166, 647-657. [CrossRef] [PubMed]

78. Jafari, Z.; Kolb, B.E.; Mohajerani, M.H. Noise Exposure Accelerates the Risk of Cognitive Impairment and Alzheimer's Disease: Adulthood, Gestational, and Prenatal Mechanistic Evidence from Animal Studies. Neurosci. Biobehav. Rev. 2020, 117, 110-128. [CrossRef] [PubMed]

79. Khosravipour, M.; Khanlari, P. The association between road transportation noise and myocardial infarction: A systematic review and meta-analysis. Sci. Total Environ. 2020, 731, 139226. [CrossRef] [PubMed]

80. Jiang, L.; Kang, J. Combined acoustical and visual performance of noise barriers in mitigating the environmental impact of motorways. Sci. Total Environ. 2016, 543, 52-60. [CrossRef] [PubMed]

81. Ohiduzzaman, M.; Sirin, O.; Kassem, E.; Rochat, J.L. State-of-the-Art Review on Sustainable Design and Construction of Quieter Pavements-Part 1: Trac Noise Measurement and Abatement Techniques. Sustainability 2016, 8, 742. [CrossRef]

82. Thomas, P.; Wei, W.; Van Renterghem, T.; Botteldooren, D. Measurement-based auralization methodology for the assessment of noise mitigation measures. J. Sound Vib. 2016, 379, 232-244. [CrossRef] 
83. Van Renterghem, T.; Botteldooren, D. Landscaping for road trac noise abatement: Model validation. Environ. Model. Softw. 2018, 109, 17-31. [CrossRef]

84. Horne, D.; Jashami, H.; Hurwitz, D.S.; Monsere, C.M.; Kothuri, S. Mitigating roadside noise pollution: A comparison between rounded and sinusoidal milled rumble strips. Transp. Res. Part D Transp. Environ. 2019, 77, 37-49. [CrossRef]

85. Kleiziene, R.; Senas, O.; Vaitkus, A.; Simanaviciene, R. Asphalt Pavement Acoustic Performance Model. Sustainability 2019, 11, 2938. [CrossRef]

86. Ferrari, A.; Novara, C.; Paolucci, E.; Vento, O.; Violante, M.; Zhang, T. Design and rapid prototyping of a closed-loop control strategy of the injected mass for the reduction of $\mathrm{CO}_{2}$, combustion noise and pollutant emissions in diesel engines. Appl. Energy 2018, 232, 358-367. [CrossRef]

87. Qin, Y.; Tang, X.; Jia, T.; Duan, Z.; Zhang, J.; Li, Y.; Zheng, L. Noise and vibration suppression in hybrid electric vehicles: State of the art and challenges. Renew. Sustain. Energy Rev. 2020, 124, 109782. [CrossRef]

88. Okraszewska, R.; Romanowska, A.; Wołek, M.; Oskarbski, J.; Birr, K.; Jamroz, K. Integration of a multilevel transport system model into sustainable Urban mobility planning. Sustainability 2018, 10, 479. [CrossRef]

89. Rackwitz, R.; Lentz, A.; Faber, M. Socio-economically sustainable civil engineering infrastructures by optimization. Struct. Saf. 2005, 27, 187-229. [CrossRef]

90. Offer, G.J.; Contestabile, M.; Howey, D.A.; Clague, R.; Brandon, N.P. Techno-economic and behavioural analysis of battery electric, hydrogen fuel cell and hybrid vehicles in a future sustainable road transport system in the UK. Energy Policy 2011, 39, 1939-1950. [CrossRef]

91. Majumdar, D.; Majhi, B.K.; Dutta, A.; Mandal, R.; Jash, T. Study on Possible Economic and Environmental Impacts of Electric Vehicle Infrastructure in Public Road Transport in Kolkata. Clean Technol. Environ. Policy 2015, 17, 1093-1101. [CrossRef]

92. Reckien, D.; Creutzig, F.; Blanca, F.; Lwasa, S.; Tovar-Restrepo, M.; McEvoy, D.; Satterthwaite, D. Climate change, equity and the Sustainable Development Goals: An urban perspective. Environ. Urban 2017, 29, 159-182. [CrossRef]

93. Henke, I.; Cartenì, A.; Molitierno, C.; Errico, A. Decision-Making in the Transport Sector: A Sustainable Evaluation Method for Road Infrastructure. Sustainability 2020, 12, 764. [CrossRef]

94. Jones, P.; Lucas, K. The social consequence of transport decision-making: Clarifying concepts, synthesising knowledge and assessing implications. J. Transp. Geogr. 2012, 21, 4-16. [CrossRef]

95. Martens, K. Transport Justice. Defining Fair Transportation Systems; Routledge: New York, NY, USA, 2017.

96. Beyazit, E. Evaluating social justice in transport: Lessons to be learned from the capability approach. Transp. Rev. 2011, 31, 117-134. [CrossRef]

97. Delbosc, A.; Currie, G. Using Lorenz curves to assess public transport equity. J. Transp. Geogr. 2011, 19, 1252-1259. [CrossRef]

98. Bertolaccini, K.; Lownes, N.E. Effects of scale and boundary selection in assessing equity of transit supply distribution. Transp. Res. Rec. 2013, 2350, 58-64. [CrossRef]

99. Welch, T.F. Equity in transport: The distribution of transit access and connectivity among ordable housing units. Transp. Policy 2013, 30, 283-293. [CrossRef]

100. Welch, T.F.; Mishra, S. A measure of equity for public transit connectivity. J. Transp. Geogr. 2013, 33, 29-41. [CrossRef]

101. Kaplan, S.; Popoks, D.; Prato, C.G.; Ceder, A. Using connectivity for measuring equity in transit provision. J. Transp. Geogr. 2014, 37, 82-92. [CrossRef]

102. Nahmias-Biran, B.-H.; Sharaby, N.; Shiftan, Y. Equity Aspects in Transportation Projects: Case Study of Transit Fare Change in Haifa. Int. J. Sustain. Transp. 2014, 8, 69-83. [CrossRef]

103. Gallo, M. Assessing the Equality of External Benefits in Public Transport Investments: The Impact of Urban Railways on Real Estate Values. Case Stud. Transp. Policy 2020, 8, 758-769. [CrossRef]

104. Camporeale, R.; Caggiani, L.; Fonzone, A.; Ottomanelli, M. Better for everyone: An approach to multimodal network design considering equity. Transp. Res. Proc. 2016, 19, 303-315. [CrossRef]

105. Camporeale, R.; Caggiani, L.; Fonzone, A.; Ottomanelli, M. Study of the accessibility inequalities of cordon-based pricing strategies using a multimodal Theil index. Transp. Plan. Technol. 2019, 42, 498-514. [CrossRef]

106. Camporeale, R.; Caggiani, L.; Fonzone, A.; Ottomanelli, M. Quantifying the impacts of horizontal and vertical equity in transit route planning. Transp. Plan. Technol. 2017, 40, 28-44. [CrossRef]

107. Camporeale, R.; Caggiani, L.; Ottomanelli, M. Modeling horizontal and vertical equity in the public transport design problem: A case study. Transp. Res. A 2019, 125, 184-206. [CrossRef]

108. Gallo, M. Improving equity of urban transit systems with the adoption of origin-destination based taxi fares. Soc. Econ. Plan. Sci. 2018, 64, 38-55. [CrossRef]

109. Caggiani, L.; Camporeale, R.; Ottomanelli, M. Facing equity in transportation Network Design Problem: A flexible constraints based model. Transp. Policy 2017, 55, 9-17. [CrossRef]

110. Rotaris, L.; Danielis, R.; Marcucci, E.; Massiani, J. The urban road pricing scheme to curb pollution in Milan, Italy: Description, impacts and preliminary cost-benefit analysis assessment. Transp. Res. A 2010, 44, 359-375. [CrossRef]

111. Invernizzi, G.; Ruprecht, A.; Mazza, R.; De Marco, M.; Sioutas, C.; Westerdahl, D. Measurement of black carbon concentration as an indicator of air quality benefits of trac restriction policies within the ecopass zone in Milan, Italy. Atmos. Environ. 2011, 45, 3522-3527. [CrossRef]

112. Percoco, M. Is road pricing effective in abating pollution? Evidence from Milan. Transp. Res. D 2013, 25, 112-118. [CrossRef] 
113. Santos, G.; Behrendt, H.; Maconi, L.; Shirvani, T.; Teytellboym, A. Part I: Externalities and economic policies in road transport. Res. Transp. Econ. 2010, 28, 2-45. [CrossRef]

114. Proost, S.; Van Dender, K. The welfare impacts of alternative policies to address atmospheric pollution in urban road transport. Reg. Sci. Urban Econ. 2001, 31, 383-411. [CrossRef]

115. Parry, I.W.H.; Bento, A. Estimating the welfare effect of congestion taxes: The critical importance of other distortions within the transport system. J. Urban Econ. 2002, 51, 339-365. [CrossRef]

116. Verhoef, E.T. Second-best congestion pricing in general networks. Heuristic algorithms for finding second-best optimal toll levels and toll points. Transp. Res. B 2002, 36, 707-729. [CrossRef]

117. Santos, G. Road fuel taxes in Europe: Do they internalize road transport externalities? Transp. Policy 2017, 53, 120-134. [CrossRef]

118. Steinsland, C.; Fridstrom, L.; Madslien, A.; Minken, H. The climate, economic and equity effects of fuel tax, road toll and commuter tax credit. Transp. Policy 2018, 72, 225-241. [CrossRef]

119. Montag, J. The simple economics of motor vehicle pollution: A case for fuel tax. Energy Policy 2015, 85, 138-149. [CrossRef]

120. Fukui, H.; Miyoshi, C. The impact of aviation fuel tax on fuel consumption and carbon emissions: The case of the US airline industry. Transp. Res. D 2017, 50, 234-253. [CrossRef]

121. Xiong, C.; Shahabi, M.; Zhao, J.; Yin, Y.; Zhou, X.; Zhang, L. An integrated and personalized traveler information and incentive scheme for energy efficient mobility systems. Transp. Res. Part C Emerg. Technol. 2020, 113, 57-73. [CrossRef]

122. Herrador, M.; Carvalho, A.; Feito, F. An Incentive-Based Solution of Sustainable Mobility for Economic Growth and $\mathrm{CO}_{2}$ Emissions Reduction. Sustainability 2015, 7, 6119-6148. [CrossRef]

123. Ricci, L.; Palmieri, P.; Ruberto, A.G.; Rocchetti, L.; Timossi, I.; Pirrotta, D.; Sala, M. Incentivizing sustainable mobility through an impact innovation methodology. CERN IdeaSq. J. Exp. Innov. 2020, 4, 25-29. [CrossRef]

124. Semanjski, I.; Lopez Aguirre, A.J.; De Mol, J.; Gautama, S. Policy 2.0 Platform for Mobile Sensing and Incentivized Targeted Shifts in Mobility Behavior. Sensors 2016, 16, 1035. [CrossRef]

125. Xie, Y.; Danaf, M.; Lima Azevedo, C.; Akkinepally, A.P.; Atasoy, B.; Jeong, K.; Seshadri, R.; Ben-Akiva, M. Behavioral Modeling of On-Demand Mobility Services: General Framework and Application to Sustainable Travel Incentives. Transportation 2019, 46, 2017-2039. [CrossRef]

126. Kacperski, C.; Kutzner, F. Financial and Symbolic Incentives Promote 'Green' Charging Choices. Transp. Res. Part F Traffic Psychol. Behav. 2020, 69, 151-158. [CrossRef]

127. Pianese, F.; Signorini, M.; Sarkar, S. Small Transactions with Sustainable Incentives. In Proceedings of the 20189 th IFIP International Conference on New Technologies, Mobility and Security (NTMS), Paris, France, 26-28 February 2018; IEEE: Piscataway, NJ, USA, 2018.

128. Storch, D.-M.; Timme, M.; Schröder, M. Incentive-Driven Transition to High Ride-Sharing Adoption. Nat. Commun. 2021, 12, 3003. [CrossRef]

129. Tian, Y.; Li, Y.; Sun, J.; Ye, J. Characterizing Favored Users of Incentive-Based Traffic Demand Management Program. Transp. Policy 2021, 105, 94-102. [CrossRef]

130. Fisher, K.; Holzwarth, S.; Chong, J.; Grant-Muller, S. How Placemaking and Positive Incentives Can Enhance Urban Walkability and Revolutionize the Citizens' Experience of Streets as Public Spaces (Symposia). J. Transp. Health 2017, 7, S86-S87. [CrossRef]

131. Eshtiaghi, K.; Aliyannezhadi, M.; Najafian, A. Identification and prioritization of factors affecting the adoption of electric vehicles using analytic network process. Int. J. Hum. Cap. Urban Manag. 2021, 6, 323-336.

132. Gao, Y.; Leng, M. Incentivizing the adoption of electric vehicles under subsidy schemes: A duopoly analysis. Oper. Res. Lett. 2021, 49, 473-476. [CrossRef]

133. Zhang, J.; Huang, J. Vehicle Product-Line Strategy under Government Subsidy Programs for Electric/Hybrid Vehicles. Transp. Res. Part E Logist. Trans. Rev. 2021, 146, 102221. [CrossRef]

134. Ouyang, D.; Zhou, S.; Ou, X. The Total Cost of Electric Vehicle Ownership: A Consumer-Oriented Study of China's Post-Subsidy Era. Energy Policy 2021, 149, 112023. [CrossRef]

135. Li, Z.; Wang, W.; Ye, M.; Liang, X. The Impact of Hydrogen Refueling Station Subsidy Strategy on China's Hydrogen Fuel Cell Vehicle Market Diffusion. Int. J. Hydrogen Energy 2021, 46, 18453-18465. [CrossRef]

136. Available online: https:/ / afdc.energy.gov/data/ (accessed on 5 June 2021).

137. Available online: https://www.dep.pa.gov/Citizens/GrantsLoansRebates/Alternative-Fuels-Incentive-Grant/pages /default. aspx (accessed on 5 June 2021).

138. Romejko, K.; Nakano, M. Portfolio Analysis of Alternative Fuel Vehicles Considering Technological Advancement, Energy Security and Policy. J. Clean. Prod. 2017, 142, 39-49. [CrossRef]

139. Brand, C.; Anable, J.; Tran, M. Accelerating the Transformation to a Low Carbon Passenger Transport System: The Role of Car Purchase Taxes, Feebates, Road Taxes and Scrappage Incentives in the UK. Transp. Res. Part A Policy Pract. 2013, 49, 132-148. [CrossRef]

140. European Academies Science Advisory Council. Decarbonisation of Transport: Options and Challenges. Available online: https://easac.eu/fileadmin/PDF_s/reports_statements/Decarbonisation_of_Tansport/EASAC_Decarbonisation_of_ Transport_FINAL_March_2019.pdf (accessed on 15 June 2021). 
141. The First Hydrogen Fuel Cell Vehicle was Created in 1966. Available online: https://interplex.com/resources/did-you-know / the-first-hydrogen-fuel-cell-vehicle-was-created-in-1966/\#: \{\}:text=The\%20First\%20Hydrogen\%20Fuel\%20Cell\%20Vehicle\% 20was\%20Created\%20in\%201966\%20\%2D\%20Interplex (accessed on 12 June 2021).

142. Wang, Q.; Xue, M.; Lin, B.-L.; Lei, Z.; Zhang, Z. Well-to-Wheel Analysis of Energy Consumption, Greenhouse Gas and Air Pollutants Emissions of Hydrogen Fuel Cell Vehicle in China. J. Clean. Prod. 2020, 275, 123061. [CrossRef]

143. Patterson, T.; Esteves, S.; Carr, S.; Zhang, F.; Reed, J.; Maddy, J.; Guwy, A. Life Cycle Assessment of the Electrolytic Production and Utilization of Low Carbon Hydrogen Vehicle Fuel. Int. J. Hydrogen Energy 2014, 39, 7190-7201. [CrossRef]

144. Wu, W.; Pai, C.-T.; Viswanathan, K.; Chang, J.-S. Comparative Life Cycle Assessment and Economic Analysis of Methanol/Hydrogen Production Processes for Fuel Cell Vehicles. J. Clean. Prod. 2021, 300, 126959. [CrossRef]

145. Wei, Q.S.; Zhang, X.; Oh, B.S. The Effect of Driving Cycles and H2 Production Pathways on the Lifecycle Analysis of Hydrogen Fuel Cell Vehicle: A Case Study in South Korea. Int. J. Hydrogen Energy 2021, 46, 7622-7633. [CrossRef]

146. Cader, J.; Koneczna, R.; Olczak, P. The Impact of Economic, Energy, and Environmental Factors on the Development of the Hydrogen Economy. Energies 2021, 14, 4811. [CrossRef]

147. Kelley, S.; Krafft, A.; Kuby, M.; Lopez, O.; Stotts, R.; Liu, J. How Early Hydrogen Fuel Cell Vehicle Adopters Geographically Evaluate a Network of Refueling Stations in California. J. Transp. Geogr. 2020, 89, 102897. [CrossRef]

148. Yu, X.; Wang, C.; He, Q. Numerical Study of Hydrogen Dispersion in a Fuel Cell Vehicle under the Effect of Ambient Wind. Int. J. Hydrogen Energy 2019, 44, 22671-22680. [CrossRef]

149. Available online: https://web.archive.org/web/20110928021638/http:/ / www.evworld.com/news.cfm?newsid=19436 (accessed on 12 June 2021).

150. Wenig, J.; Sodenkamp, M.; Staake, T. Battery versus Infrastructure: Tradeoffs between Battery Capacity and Charging Infrastructure for Plug-in Hybrid Electric Vehicles. Appl. Energy 2019, 255, 113787. [CrossRef]

151. Chakraborty, D.; Bunch, D.S.; Lee, J.H.; Tal, G. Demand Drivers for Charging Infrastructure-Charging Behavior of Plug-in Electric Vehicle Commuters. Transp. Res. D Transp. Environ. 2019, 76, 255-272. [CrossRef]

152. Rahman, I.; Vasant, P.M.; Singh, B.S.M.; Abdullah-Al-Wadud, M.; Adnan, N. Review of Recent Trends in Optimization Techniques for Plug-in Hybrid, and Electric Vehicle Charging Infrastructures. Renew. Sustain. Energy Rev. 2016, 58, 1039-1047. [CrossRef]

153. Nazari, F.; Mohammadian, A.K.; Stephens, T. Modeling Electric Vehicle Adoption Considering a Latent Travel Pattern Construct and Charging Infrastructure. Transp. Res. D Transp. Environ. 2019, 72, 65-82. [CrossRef]

154. Hao, X.; Wang, H.; Ouyang, M. A Novel State-of-Charge-Based Method for Plug-in Hybrid Vehicle Electric Distance Analysis Validated with Actual Driving Data. Mitig. Adapt. Strateg. Glob. Chang. 2020, 25, 459-475. [CrossRef]

155. Greene, D.L.; Kontou, E.; Borlaug, B.; Brooker, A.; Muratori, M. Public Charging Infrastructure for Plug-in Electric Vehicles: What Is It Worth? Transp. Res. D Transp. Environ. 2020, 78, 102182. [CrossRef]

156. Available online: https:/ / www.energy.gov / articles/history-electric-car (accessed on 9 June 2021).

157. Glos, J.; Otava, L.; Vaclavek, P. Non-Linear Model Predictive Control of Cabin Temperature and Air Quality in Fully Electric Vehicles. IEEE Trans. Veh. Technol. 2021, 70, 1216-1229. [CrossRef]

158. Choi, H.; Koo, Y. Effectiveness of Battery Electric Vehicle Promotion on Particulate Matter Emissions Reduction. Transp. Res. D Transp. Environ. 2021, 93, 102758. [CrossRef]

159. Hou, F.; Chen, X.; Chen, X.; Yang, F.; Ma, Z.; Zhang, S.; Liu, C.; Zhao, Y.; Guo, F. Comprehensive Analysis Method of Determining Global Long-Term GHG Mitigation Potential of Passenger Battery Electric Vehicles. J. Clean. Prod. 2021, 289, 125137. [CrossRef]

160. Schaut, S.; Sawodny, O. Thermal Management for the Cabin of a Battery Electric Vehicle Considering Passengers' Comfort. IEEE Trans. Control Syst. Technol. 2020, 28, 1476-1492. [CrossRef]

161. Wu, Y.; Zhang, J.; Ravey, A.; Chrenko, D.; Miraoui, A. Real-Time Energy Management of Photovoltaic-Assisted Electric Vehicle Charging Station by Markov Decision Process. J. Power Sour. 2020, 476, 228504. [CrossRef]

162. Al Wahedi, A.; Bicer, Y. Development of an Off-Grid Electrical Vehicle Charging Station Hybridized with Renewables Including Battery Cooling System and Multiple Energy Storage Units. Energy Rep. 2020, 6, 2006-2021. [CrossRef]

163. Karmaker, A.K.; Ahmed, M.R.; Hossain, M.A.; Sikder, M.M. Feasibility Assessment \& Design of Hybrid Renewable Energy Based Electric Vehicle Charging Station in Bangladesh. Sustain. Cities Soc. 2018, 39, 189-202.

164. Lassioui, A.; EL Fadil, H.; Rachid, A.; Bouanou, T.; Giri, F. Adaptive Output Feedback Nonlinear Control of a Wireless Power Transfer Charger for Battery Electric Vehicle. J. Control Autom. Electr. Syst. 2021, 32, 492-506. [CrossRef]

165. Lin, Y.; Zhang, K.; Shen, Z.-J.M.; Miao, L. Charging Network Planning for Electric Bus Cities: A Case Study of Shenzhen, China. Sustainability 2019, 11, 4713. [CrossRef]

166. Helmus, J.R.; Lees, M.H.; van den Hoed, R. A Data Driven Typology of Electric Vehicle User Types and Charging Sessions. Transp. Res. Part C Emerg. Technol. 2020, 115, 102637. [CrossRef]

167. Faddel, S.; Mohammed, O.A. Automated Distributed Electric Vehicle Controller for Residential Demand Side Management. IEEE Trans. Ind. Appl. 2019, 55, 16-25. [CrossRef]

168. Chen, X.; Leung, K.-C.; Lam, A.Y.S.; Hill, D. Online Scheduling for Hierarchical Vehicle-to-Grid System: Design, Formulation, and Algorithm. IEEE Trans. Veh. Technol. 2018, 68, 1302-1317. [CrossRef]

169. Moon, H.; Park, S.Y.; Jeong, C.; Lee, J. Forecasting Electricity Demand of Electric Vehicles by Analyzing Consumers' Charging Patterns. Transp. Res. D Transp. Environ. 2018, 62, 64-79. [CrossRef] 
170. Available online: https://energyeducation.ca/encyclopedia/Natural_gas_vehicle\#/find/nearest?fuel=CNG (accessed on 10 June 2021).

171. Heber, L.; Schwab, J. Modelling of a Thermoelectric Generator for Heavy-Duty Natural Gas Vehicles: Techno-Economic Approach and Experimental Investigation. Appl. Therm. Eng. 2020, 174, 115156. [CrossRef]

172. Li, Y.; Xue, J.; Peppers, J.; Kado, N.Y.; Vogel, C.F.A.; Alaimo, C.P.; Green, P.G.; Zhang, R.; Jenkins, B.M.; Kim, M.; et al. Chemical and Toxicological Properties of Emissions from a Light-Duty Compressed Natural Gas Vehicle Fueled with Renewable Natural Gas. Environ. Sci. Technol. 2021, 55, 2820-2830. [CrossRef] [PubMed]

173. Almohamadi, H.; Alamoudi, M.A.; Smith, K.J. Washcoat Overlayer for Improved Activity and Stability of Natural Gas Vehicle Monolith Catalysts Operating in the Presence of $\mathrm{H}_{2} \mathrm{O}$ and $\mathrm{SO}_{2}$. Ind. Eng. Chem. Res. 2021, 60, 3572-3580. [CrossRef]

174. Weiss, B.; Beutel, T.W.; Chapman, B.R.; Saathoff, J.D.; Merchant, S.; Majano, G.J.; Weissman, W. Onboard Natural Gas Reforming for Heavy Duty Vehicles. SAE Int. J. Commer. Veh. 2019, 12, 45-56. [CrossRef]

175. Stiaccini, I.; Galoppi, G.; Balduzzi, F.; Sacco, M.; Santoni, S.; Ferrara, G. Analysis of Valve-Retainer Orientation Influence on a Reciprocating Compressor for Natural Gas Vehicle Refueling Stations. J. Nat. Gas Sci. Eng. 2017, 38, 516-526. [CrossRef]

176. Zhang, J.; Tan, Y.; Zhang, T.; Yu, K. Investigation of Improvement of Desorption Efficiency Using Engine Cooling Water in Natural Gas Vehicle Tank. Appl. Therm. Eng. 2018, 133, 117-124. [CrossRef]

177. Available online: https://www.bharatpetroleum.com/images/files/Biodiesel(2).pdf (accessed on 9 June 2021).

178. Botero, M.L.; Mendoza, C.; Arias, S.; Hincapié, O.D.; Agudelo, J.R.; Ortiz, I.C. In vitro evaluation of the cytotoxicity, mutagenicity and DNA damage induced by particle matter and gaseous emissions from a medium-duty diesel vehicle under real driving conditions using palm oil biodiesel blends. Environ. Pollut. 2020, 265, 115034. [CrossRef] [PubMed]

179. Shen, X.; Shi, J.; Cao, X.; Zhang, X.; Zhang, W.; Wu, H.; Yao, Z. Real-world exhaust emissions and fuel consumption for diesel vehicles fueled by waste cooking oil biodiesel blends. Atmos. Environ. 2018, 191, 249-257. [CrossRef]

180. Anderson, J.E.; Collings, T.R.; Mueller, S.A.; Ball, J.C.; Wallington, T.J. Soy Biodiesel Oxidation at Vehicle Fuel System Temperature: Influence of Aged Fuel on Fresh Fuel Degradation to Simulate Refueling. SAE Int. J. Fuels Lubr. 2017, 10, 296-303. [CrossRef]

181. Sonthalia, A.; Kumar, N. Comparison of Fuel Characteristics of Hydrotreated Waste Cooking Oil with Its Biodiesel and Fossil Diesel. Environ. Sci. Pollut. Res. Int. 2021, 28, 11824-11834. [CrossRef] [PubMed]

182. Dariusz Kurczynski. Impact of RME biodiesel on the concentration of particulates and nitrogen oxides in compression ignition engine exhaust fumes. In 2020 XII International Science-Technical Conference Automotive Safety; IEEE: Piscataway, NJ, USA, 2020. [CrossRef]

183. Koponen, K.; Nylund, N.-O. IEA technology network cooperation: Fuel and technology alternatives for buses: Overall energy efficiency and emissions. SAE Int. J. Commer. Veh. 2012, 5, 515-533. [CrossRef]

184. Puricelli, S.; Cardellini, G.; Casadei, S.; Faedo, D.; van den Oever, A.E.M.; Grosso, M. A Review on Biofuels for Light-Duty Vehicles in Europe. Renew. Sustain. Energy Rev. 2021, 137, 110398.

185. Puškár, M.; Jahnátek, A.; Kuric, I.; Kádárová, J.; Kopas, M.; Šoltésová, M. Complex Analysis Focused on Influence of Biodiesel and Its Mixture on Regulated and Unregulated Emissions of Motor Vehicles with the Aim to Protect Air Quality and Environment. Air Qual. Atmos. Health 2019, 12, 855-864. [CrossRef]

186. Kpan, J.D.A.; Krahl, J. Sustaining the Oxidation Stability of Biodiesel and Its Blends in Plug-in Hybrid Vehicles Using Adsorbents. Energy Fuels 2019, 33, 11181-11186. [CrossRef]

187. Reksowardojo, I.K.; Setiapraja, H.; Fajar, R.; Wibowo, E.; Kusdiana, D. An Investigation of Laboratory and Road Test of Common Rail Injection Vehicles Fueled with B20 Biodiesel. Energies 2020, 13, 6118. [CrossRef]

188. Masmoudi, M.A.; Hosny, M.; Demir, E.; Cheikhrouhou, N. A Study on the Heterogeneous Fleet of Alternative Fuel Vehicles: Reducing $\mathrm{CO}_{2}$ Emissions by Means of Biodiesel Fuel. Transp. Res. D Transp. Environ. 2018, 63, 137-155. [CrossRef]

189. Targino, A.C.; Krecl, P.; Cipoli, Y.A.; Oukawa, G.Y.; Monroy, D.A. Bus Commuter Exposure and the Impact of Switching from Diesel to Biodiesel for Routes of Complex Urban Geometry. Environ. Pollut. 2020, 263, 114601. [CrossRef] [PubMed]

190. Köse, S.; Aylanşik, G.; Babagiray, M.; Kocakulak, T. Biodiesel Production from Waste Sunflower Oil and Engine Performance Tests. Int. J. Automot. Sci. Technol. 2020, 4, 206-212. [CrossRef]

191. Ong, H.C.; Mahlia, T.M.I.; Masjuki, H.H.; Norhasyima, R.S. Comparison of Palm Oil, Jatropha Curcas and Calophyllum Inophyllum for Biodiesel: A Review. Renew. Sustain. Energy Rev. 2011, 15, 3501-3515. [CrossRef]

192. Datla, R.; Puli, R.K.; Velayudhan Parvathy, C.; Varuvel, E.G. Effect of Start of Main Injection Timing on Performance, Emission, and Combustion Characteristics of a VGT CI Engine Fueled with Neem Biodiesel. Environ. Sci. Pollut. Res. Int. 2021, 28, 11942-11953. [CrossRef]

193. Ramos, Á.; García-Contreras, R.; Armas, O. Performance, Combustion Timing and Emissions from a Light Duty Vehicle at Different Altitudes Fueled with Animal Fat Biodiesel, GTL and Diesel Fuels. Appl. Energy 2016, 182, 507-517. [CrossRef]

194. Hoang, A.T. Combustion Behavior, Performance and Emission Characteristics of Diesel Engine Fuelled with Biodiesel Containing Cerium Oxide Nanoparticles: A Review. Fuel Process. Technol. 2021, 218, 106840. [CrossRef]

195. Azizah, T.N.; Ramadhanty, A.P.; Feranika, N. Extraction Solvents Composition Effect in Biodiesel Production from Microalgae Consortium Botryococcus Braunii and Dunaliella sp. Khazanah J. Mhs. 2020, 12, 46-51. [CrossRef]

196. García-Contreras, R.; Agudelo, A.; Gómez, A.; Fernández-Yáñez, P.; Armas, O.; Ramos, Á. Thermoelectric Energy Recovery in a Light-Duty Diesel Vehicle under Real-World Driving Conditions at Different Altitudes with Diesel, Biodiesel and GTL Fuels. Energies 2019, 12, 1105. [CrossRef] 
197. Sonthalia, A.; Garg, S.; Sharma, R.; Subramanian, T.; Kumar, N. Effect of Electrostatic Precipitator on Exhaust Emissions in Biodiesel Fuelled CI Engine. Environ. Sci. Pollut. Res. Int. 2021, 28, 11850-11859. [CrossRef]

198. Zhang, L.; Bai, W. Sustainability of Crop-Based Biodiesel for Transportation in China: Barrier Analysis and Life Cycle Ecological Footprint Calculations. Technol. Forecast. Soc. Chang. 2021, 164, 120526. [CrossRef]

199. Mueller, S.A.; Anderson, J.E.; Wallington, T.J. Impact of Biofuel Production and Other Supply and Demand Factors on Food Price Increases in 2008. Biomass Bioenergy 2011, 35, 1623-1632. [CrossRef]

200. Romprasert, S.; Jermsittiparsert, K. Energy Risk Management and Cost of Economic Production Biodiesel Project. Int. J. Energy Econ. Policy 2019, 9, 349-357. [CrossRef]

201. Khang, D.S.; Tan, R.R.; Uy, O.M.; Promentilla, M.A.B.; Tuan, P.D.; Abe, N.; Razon, L.F. A Design of Experiments Approach to the Sensitivity Analysis of the Life Cycle Cost of Biodiesel. Clean Technol. Environ. Policy 2018, 20, 573-580. [CrossRef]

202. E, J.; Pham, M.; Zhao, D.; Deng, Y.; Le, D.; Zuo, W.; Zhu, H.; Liu, T.; Peng, Q.; Zhang, Z. Effect of Different Technologies on Combustion and Emissions of the Diesel Engine Fueled with Biodiesel: A Review. Renew. Sustain. Energy Rev. 2017, 80, 620-647. [CrossRef]

203. Knoope, M.M.J.; Balzer, C.H.; Worrell, E. Analysing the Water and Greenhouse Gas Effects of Soya Bean-Based Biodiesel in Five Different Regions. Glob. Chang. Biol. Bioenergy 2019, 11, 381-399. [CrossRef]

204. Markatou, M. Planning and sustainable urban mobility plans: Parallel orbits or incompatible paths? J. Traffic Transp. Eng. 2020, 8, 63-72. [CrossRef]

205. Sdoukopoulos, E.; Kose, P.; Gal-Tzur, A.; Mezghani, M.; Boile, M.; Sheety, E.; Mitropoulos, L. Assessment of Urban Mobility Needs, Gaps and Priorities in Mediterranean Partner Countries. Transp. Res. Procedia 2016, 14, 1211-1220. [CrossRef]

206. Das, H.S.; Rahman, M.M.; Li, S.; Tan, C.W. Electric vehicles standards, charging infrastructure, and impact on grid integration: A technological review. Renew. Sustain. Energy Rev. 2020, 120, 109618. [CrossRef]

207. Salvatti, G.A.; Carati, E.G.; Cardoso, R.; da Costa, J.P.; Stein, C.M.D.O. Electric Vehicles Energy Management with V2G/G2V Multifactor Optimization of Smart Grids. Energies 2020, 13, 1191. [CrossRef]

208. Guille, C.; Gross, G. A conceptual framework for the vehicle-to-grid (V2G) implementation. Energy Policy 2009, 37, 4379-4390. [CrossRef]

209. eRoadArlanda: The Technology. Available online: https:/ / eroadarlanda.com/the-technology/ (accessed on 30 May 2020).

210. Wu, H.H.; Gilchrist, A.; Sealy, K.; Israelsen, P.; Muhs, J. A review on inductive charging for electric vehicles. In Proceedings of the IEEE International Electric Machines and Drives Conference, Niagara Falls, ON, Canada, 15-18 May 2011; pp. 143-147.

211. Caldeira, C.; Quinteiro, P.; Castanheira, E.; Boulay, A.-M.; Dias, A.C.; Arroja, L.; Freire, F. Water Footprint Profile of Crop-Based Vegetable Oils and Waste Cooking Oil: Comparing Two Water Scarcity Footprint Methods. J. Clean. Prod. 2018, 195, 1190-1202. [CrossRef]

212. Karavalakis, G.; Gysel, N.; Schmitz, D.A.; Cho, A.K.; Sioutas, C.; Schauer, J.J.; Cocker, D.R.; Durbin, T.D. Impact of Biodiesel on Regulated and Unregulated Emissions, and Redox and Proinflammatory Properties of PM Emitted from Heavy-Duty Vehicles. Sci. Total Environ. 2017, 584, 1230-1238. [CrossRef]

213. Arias, S.; Molina, F.; Agudelo, J.R. Palm Oil Biodiesel: An Assessment of PAH Emissions, Oxidative Potential and Ecotoxicity of Particulate Matter. J. Environ. Sci. 2021, 101, 326-338. [CrossRef]

214. Marge, R.; Iovan, S.; Iovan, A. Sustainable Mobility for Public Transport. In Annals of the 'Constantin Brâncuşi' University of Targu Jiu: Letters and Social Sciences Series; University Constantin Brancusi of Targu Jiu: Targu Jiu, Romania, 2017; pp. 193-197.

215. Becker, H.; Ciari, F.; Axhausen, K.W. Comparing car-sharing schemes in Switzerland: User groups and usage patterns. Transp. Res. Part A Policy Pract. 2017, 97, 17-29. [CrossRef]

216. Zavada, J.B.; Abramovi 'c, B.; Šipuš, D. A Strategic Model of Sustainable Mobility in the city of Zagreb and its Surrounding Area. Int. J. Trac Transp. Eng. 2017, 7, 430-442.

217. Tafidis, P.; Sdoukopoulos, A.; Pitsiava-Latinopoulou, M. Sustainable urban mobility indicators: Policy versus practice in the case of Greek cities. Transp. Res. Procedia 2017, 24, 304-312. [CrossRef]

218. Machado, C.A.S.; de Salles Hue, N.P.M.; Berssaneti, F.T.; Quintanilha, J.A. An overview of shared mobility. Sustainability 2018, 10, 4342. [CrossRef]

219. Mourad, A.; Puchinger, J.; Chu, C. A survey of models and algorithms for optimizing shared mobility. Trans. Res. Part B Methodol. 2019, 123, 323-346. [CrossRef]

220. Akyelken, N.; Givoni, M.; Salo, M.; Plepys, A.; Judl, J.; Anderton, K.; Koskela, S. The importance of institutions and policy settings for car sharing-evidence from the UK, Israel, Sweden and Finland. Eur. J. Transp. Infrastruct. Res. 2018, 18, 340-359.

221. Giesel, F.; Nobis, C. The impact of carsharing on car ownership in German cities. Transp. Res. Procedia 2016, 19, 215-224. [CrossRef]

222. Schor, J. Debating the Sharing Economy. J. Self-Gov. Manag. Econ. 2017, 4, 7-22.

223. Ye, J.; Wang, D.; Li, X.; Axhausen, K.W.; Jin, Y. Assessing one-way carsharing's impacts on vehicle ownership: Evidence from Shanghai with an international comparison. Transp. Res. Part A Policy Pract. 2021, 150, 16-32. [CrossRef]

224. Inturri, G.; Fiore, S.; Ignaccolo, M.; Caprì, S.; Pira, M.L. "You Study, You Travel Free”: When Mobility Management Strategies Meet Social Objectives. Transp. Res. Procedia 2020, 45, 193-200. [CrossRef]

225. Inturri, G.; Giuffrida, N.; Le Pira, M.; Fazio, M.; Ignaccolo, M. Linking Public Transport User Satisfaction with Service Accessibility for Sustainable Mobility Planning. ISPRS Int. J. Geo-Inf. 2021, 10, 235. [CrossRef] 
226. Buck, C.; Pohlabeln, H.; Huybrechts, I.; De Bourdeaudhuij, I.; Pitsiladis, Y.; Reisch, L.; Pigeot, I. Development and application of a moveability index to quantify possibilities for physical activity in the built environment of children. Health Place 2011, 17, 1191-1201. [CrossRef] [PubMed]

227. D’Alessandro, D.; Arletti, S.; Azara, A.; Buffoli, M.; Capasso, L.; Cappuccitti, A.; Casuccio, A.; Cecchini, A.; Costa, G.; De, A.M.M. Strategies for disease prevention and health promotion in urban areas: The erice 50 charter. Ann. Ig. Med. Prev. Comunità 2017, 29, 481-493. [CrossRef]

228. Forsyth, A.; Southworth, M. Cities Afoot-Pedestrians, walkability and urban design. J. Urban Des. 2008, 13, 1-3. [CrossRef]

229. Saelens, B.E.; Sallis, J.F.; Black, J.B.; Chen, D. Neighborhood-Based differences in physical activity: An environment scale evaluation. Am. J. Public Health 2003, 93, 1552-1558. [CrossRef]

230. Garin, N.; Olaya, B.; Miret, M.; Ayuso-Mateos, J.L.; Power, M.; Bucciarelli, P.; Haro, J.M. Built environment and elderly population health: A comprehensive literature review. Clin. Pract. Epidemiol. Ment. Health 2014, 10, 103-115. [CrossRef] [PubMed]

231. Zuniga-Teran, A.A.; Orr, B.J.; Gimblett, R.H.; Chalfoun, N.V.; Guertin, D.P.; Marsh, S.E. Neighborhood design, physical activity, and wellbeing: Applying the walkability model. Int. J. Environ. Res. Public Health 2017, 14, 76. [CrossRef] [PubMed]

232. Clifton, K.J.; Livi Smith, A.D.; Rodriguez, D. The development and testing of an audit for the pedestrian environment. Landsc. Urban Plan. 2007, 80, 95-110. [CrossRef]

233. Van Dyck, D.; Cardon, G.; Deforche, B.; De Bourdeaudhuij, I. Do adults like living in high-walkable neighborhoods? Associations of walkability parameters with neighborhood satisfaction and possible mediators. Health Place 2011, 17, 971-977. [CrossRef] [PubMed]

234. Van Dyck, D.; Cerin, E.; Conway, T.L.; De Bourdeaudhuij, I.; Owen, N.; Kerr, J.; Cardon, G.; Frank, L.D.; Saelens, B.E.; Sallis, J.F. Perceived neighborhood environmental attributes associated with adults' leisure-time physical activity: Findings from Belgium, Australia and the USA. Health Place 2013, 19, 59-68. [CrossRef]

235. Forsyth, A. What is a walkable place? The walkability debate in urban design. Urban Des. Int. 2015, 20, 274-292. [CrossRef]

236. Cervero, R.; Duncan, M. Walking, bicycling, and urban landscapes: Evidence from the San Francisco Bay area. Am. J. Public Health 2003, 93, 1478-1483. [CrossRef]

237. Sundquist, K.; Eriksson, U.; Kawakami, N.; Skog, L.; Ohlsson, H.; Arvidsson, D. Neighborhood walkability, physical activity, and walking behavior: The Swedish neighborhood and physical activity (SNAP) study. Soc. Sci. Med. 2011, 72, 1266-1273. [CrossRef]

238. Blečić, I.; Congiu, T.; Fancello, G.; Trunfio, G.A. Planning and Design Support Tools for Walkability: A Guide for Urban Analysts. Sustainability 2020, 12, 4405. [CrossRef]

239. Frank, L.D.; Sallis, J.F.; Conway, T.L.; Chapman, J.E.; Saelens, B.E.; Bachman, W. Many pathways from land use to health. J. Am. Plan. Assoc. 2006, 72, 75-87. [CrossRef]

240. Livi, A.D.; Clifton, K.J. Issues and methods in capturing pedestrian behaviors, attitudes and perceptions: Experiences with a community-based walkability survey. In Proceedings of the Transportation Research Board, Annual Meeting, Washington, DC, USA, 11-15 January 2004.

241. Páez, A. Mapping travelers' attitudes: Does space matter? J. Transp. Geogr. 2013, 26, 117-125. [CrossRef]

242. Porta, S.; Renne, J.L. Linking urban design to sustainability: Formal indicators of social urban sustainability field research in Perth, Western Australia. Urban Des. Int. 2005, 10, 51-64. [CrossRef]

243. Speck, J. Walkable City: How Downtown Can Save America, One Step at a Time; North Point Press: New York, NY, USA, 2012.

244. Kelly, C.E.; Tight, M.R.; Hodgson, F.C.; Page, M.W. A comparison of three methods for assessing the walkability of the pedestrian environment. J. Transp. Geogr. 2011, 19, 1500-1508. [CrossRef]

245. Lindelow, D.; Svensson, A.; Sternudd, C.; Johansson, M. What limits the pedestrian? Exploring perceptions of walking in the built environment and in the context of every-day life. J. Transp. Health 2014, 1, 223-231. [CrossRef]

246. Binetti, M.; Caggiani, L.; Camporeale, R.; Ottomanelli, M. A Sustainable Crowdsourced Delivery System to Foster Free-Floating Bike-Sharing. Sustainability 2019, 11, 2772. [CrossRef]

247. Yang, Y.; Wu, X.; Zhou, P.; Gou, Z.; Lu, Y. Towards a cycling-friendly city: An updated review of the associations between built environment and cycling behaviors (2007-2017). J. Transp. Health 2019, 14, 100613. [CrossRef]

248. Appolloni, L.; Corazza, M.V.; D’Alessandro, D. The Pleasure of Walking: An Innovative Methodology to Assess Appropriate Walkable Performance in Urban Areas to Support Transport Planning. Sustainability 2019, 11, 3467. [CrossRef]

249. Eren, E.; Uz, V.E. A review on bike-sharing: The factors affecting bike-sharing demand. Sustain. Cities Soc. $2020,54,101882$. [CrossRef]

250. Fistola, R.; Gallo, M.; La Rocca, R.A.; Russo, F. The Effectiveness of Urban Cycle Lanes: From Dyscrasias to Potential Solutions. Sustainability 2020, 12, 2321. [CrossRef]

251. McLeod, S.; Babb, C.; Barlow, S. How to 'do' a bike plan: Collating best practices to synthesise a Maturity Model of planning for cycling. Transp. Res. Interdiscip. Perspect. 2020, 5, 100130. [CrossRef]

252. Cervero, R.; Radisch, C. Travel choices in pedestrian versus automobile oriented neighborhoods. Transp. Policy 1996, 3, 127-141. [CrossRef]

253. Arroyo, R.; Mars, L.; Ruiz, T. Perceptions of Pedestrian and Cyclist Environments, Travel Behaviors, and Social Networks. Sustainability 2018, 10, 3241. [CrossRef]

254. Fistola, R.; Gallo, M.; La Rocca, R.A.; Raimondo, M. Soft mobility in the "oblique city". In Town and Infrastructure Planning for Safety and Urban Quality; Pezzagno, M., Tira, M., Eds.; Taylor \& Francis Group: London, UK, 2018; pp. 319-326. 
255. Freudendal-Pedersen, M.; Hartmann-Petersen, K.; Friis, F.; Rudolf Lindberg, M.; Grindsted, T.S. Sustainable Mobility in the Mobile Risk Society-Designing Innovative Mobility Solutions in Copenhagen. Sustainability 2020, 12, 7218. [CrossRef]

256. Roadmap to a Single European Transport Area-Towards a Competitive and Resource Efficient Transport System. In White Paper, Communication; European Commission: Brussels, Belgium, 2011; p. 144.

257. Reflection Paper: Towards a Sustainable Europe by 2030; European Commission: Brussels, Belgium, 2019 ; p. 22.

258. A European Strategy for Low-Emission Mobility. In Communication from the Commission to the European Parliament, the Council, the European Economic and Social Committee and the Committee of the Regions; European Commission: Brussels, Belgium, 2016 ; p. 501.

259. Available online: https:/ / transport.ec.europa.eu/index_en (accessed on 5 July 2021).

260. Consult, R. (Ed.) Guidelines for Developing and Implementing a Sustainable Urban Mobility Plan, 2nd ed.; European Platform on Sustainable Urban Mobility Plans: Cologne, Germany, 2019.

261. Eltis. Available online: https:/ / www.eltis.org/mobility-plans/city-database (accessed on 20 May 2020).

262. Zhou, J. Sustainable transportation in the US: A review of proposals, policies, and programs since 2000. Front. Archit. Res. 2012, 1, 150-165. [CrossRef] 